\title{
A new genus and five new species of the subfamily Florarctinae (Tardigrada, Arthrotardigrada)
}

\author{
Jesper G. HANSEN ${ }^{\circledR 1, *}$ \& Reinhardt M. KRISTENSEN ${ }^{\circledR} 2$ \\ ${ }^{1,2}$ Natural History Museum of Denmark, University of Copenhagen, \\ Universitetsparken 15, DK-2100 Copenhagen Ø, Denmark. \\ ${ }^{*}$ Corresponding author: jesperguldberg@gmail.com \\ 2Email: RMKristensen@snm.ku.dk \\ ${ }^{1}$ urn:Isid:zoobank.org:author:6E3A7AE9-0269-4FAB-B51B-1C2643F7C30D \\ ${ }^{2}$ urn:lsid:zoobank.org:author:4BA89040-D79E-41C1-A17C-539FBB9B6BA4
}

\begin{abstract}
A new genus Higginsarctus gen. nov. in the subfamily Florarctinae Renaud-Mornant, 1982 (Arthrotardigrada) is established on the basis of the type species H. signeae gen. et sp. nov. described from carbonated sand habitats from Faroe Bank, North Atlantic Ocean. Three other Atlantic species H. laurae gen. et sp. nov., H. martini gen. et sp. nov. and H. shintai gen. et sp. nov. are described from Dentalium sand, Roscoff, France and finally H. lassei gen. et sp. nov. is described from the deep sea in the South Pacific Ocean off the coast of Chile. The recently described species Ligiarctus alatus GomesJúnior, E. Santos, da Rocha, P.J.P. Santos \& Fontoura, 2018 is investigated and compared with the type species Ligiarctus eastwardi Renaud-Mornant, 1982. New and additional information to the original description of L. alatus is provided and this species is moved to Higginsarctus gen. nov. as H. alatus comb. nov.
\end{abstract}

Keywords. Interstitial, marine subtidal tardigrades, Florarctinae, Ligiarctus, Higginsarctus gen. nov.

Hansen J.G. \& Kristensen R.M. 2021. A new genus and five new species of the subfamily Florarctinae (Tardigrada, Arthrotardigrada). European Journal of Taxonomy 762: 149-184. https://doi.org/10.5852/ejt.2021.762.1461

\section{Introduction}

The subfamily Florarctinae of the exclusively marine tardigrade order Arthrotardigrada was established by Renaud-Mornant (1982) and later emended by Kristensen (1984) and Gąsiorek et al. (2021). It is characterized mainly by the presence of lobate aliform cuticular expansions and hook-shaped peduncles supporting the digits. At present, the subfamily includes 22 species attributed to the three genera Florarctus Delamare-Deboutteville \& Renaud-Mornant, 1965 (15 species), Ligiarctus Renaud-Mornant, 1982 (2 species) and Wingstrandarctus Kristensen, 1984 (5 species). The main features separating these genera are the presence/absence of ceasti in the alae, total number of alae (1,4 or 6), internal claw structures (avicularium or notch) and the morphology of the primary clavae. 
In this study, five new species of Florarctinae are described sharing a unique configuration of the supporting epicuticle of the alae and number of alae (8). Three of these are each described on the basis of a single individual but they are justified for the importance of describing the new taxa and the difficulty in collecting them. Based on the five new species, a new genus is erected and the diagnosis of the subfamily Florarctinae is amended to include the new genus. Furthermore, Ligiarctus alatus Gomes-Júnior, E. Santos, da Rocha, P.J.P. Santos \& Fontoura, 2018 is transferred to the new genus as Higginsarctus alatus gen. et comb. nov. and the diagnosis of the genus Ligiarctus is amended.

The new genus was first discovered in 1982, among a very rich tardigrade fauna associated with the first described loriciferan (Kristensen 1983; Kristensen \& Renaud-Mornant 1983; Renaud-Mornant 1989) found off the coast of Roscoff, France. A year later, another species of the new genus was found in deepsea sediment $(2475 \mathrm{~m})$ which had been collected in 1966 in the South Pacific Ocean, off the coast of Chile. Also in 1983, further specimens belonging to the new genus were collected in the North Atlantic Ocean, off the coast of Cape Romain, South Carolina, USA. Finally, an additional species was collected at the Faroe Bank, North Atlantic Ocean in 1992 and 1998 (Hansen et al. 2001; Hansen 2004, 2005), where males were found for the first time.

\section{Material and methods}

The new material treated here has been deposited in the collections of the National History Museum of Denmark (NHMD). Type material of Ligiarctus eastwardi Renaud-Mornant, 1982 was borrowed from the Muséum national d'histoire naturelle, Paris, France (MNHN), and of Ligiarctus alatus from the collection of P. Fontoura (Department of Biology, Faculty of Sciences, University of Porto, Portugal).

The material studied was compiled over many years and derived from several collection campaigns listed below.

Higginsarctus lassei gen. et sp. nov. was collected in 1966 during cruise 17 of the American R/V Anton Bruun, in the Southeastern Pacific Ocean. A Phleger corer was applied to collect the bioclastic (so called Globerina-sand) sediments at $2475 \mathrm{~m}$ depth. Meiofauna was extracted from the sample by Robert P. Higgins who also mounted the glycerin-impregnated specimen between two coverslips on a Cobb aluminum slide frame.

Higginsarctus laurae gen. et sp. nov., H. martini gen. et sp. nov. and $H$. shintai gen. et sp. nov. were collected with a Sanders dredge from the upper surface layer of shelly gravel, Dentalium sand, also known as 'Sable Dentalium', at 25-30 m depth, near Roscoff, France, in 1982 (Kristensen 1983; Renaud-Mornant 1989). The sample was fresh-water shocked, decanted through a $62 \mu \mathrm{m}$ mesh net and fixed in $4 \%$ buffered formaldehyde. Specimens were sorted using a stereo microscope at $40 \times$ magnification and subsequently mounted on micro slides in glycerin. Initial photomicrographs of the specimens were taken on a Zeiss Ultraphot III microscope prior to the infusion of glycerin (as glycerin may dissolve the stylets and placoids). Observations and measurements were performed on an Olympus BX51 microscope.

Higginsarctus signeae gen. et sp. nov. from the Faroe Bank was encountered during expeditions in 1992 and 1998 as part of the Inter-Nordic project known as BIOFAR ('Biology of the Faroe Islands'). BIOFAR Stations 786 and 788 were collected with an anchor dredge from the Faroese Coast Guard vessel Olavur Halgi (1992) and BIOFAR Stations 2013 was collected with a triangular dredge from R/V Magnus Heinason of the Faroese Fishery Investigations (1998). Details on the sampling-localities are provided in Nørrevang et al. (1994) and Hansen et al. (2001, 2003). To release the tardigrades from the sediment, a number of sub-samples at each station were fresh-water shocked (following Kristensen 1983), decanted through a $32 \mu \mathrm{m}$ mesh net and fixed in $4 \%$ buffered formaldehyde for later sorting. 
Specimens were sorted using a stereo microscope at $40 \times$ magnification. A single specimen was prepared for scanning electron microscopy (SEM) and the rest of the specimens were mounted on micro slides in glycerin. Observations and measurements were performed on an Olympus BX51 microscope. The specimen prepared for SEM was dehydrated in an ethanol/acetone series prior to critical point drying. The dried specimen were mounted on an aluminium stub and coated with palladium for observation in a JEOL JSM-6335-F SEM.

Higginsarctus gen. et sp. nov. was collected about $195 \mathrm{~km}$ E of Cape Romain on the continental shelf of the coast of South Carolina, USA during a cruise of the R/V Cape Hatteras, 19 November 1983. A Higgins anchor dredge was applied to collect the sediments at $289 \mathrm{~m}$ depth. Meiofauna was extracted from the sample by Robert P. Higgins. The three glycerin-impregnated specimens were mounted by Reinhardt M. Kristensen on a glass slide with a cover slide and sealed with Glyceel.

Ligiarctus eastwardi was collected about $195 \mathrm{~km}$ E of Cape Fear on the continental shelf of the coast of North Carolina, USA during a cruise of the R/V Cape Hatteras, 16 November 1983. A Higgins anchor dredge was applied to collect the sediments at $439 \mathrm{~m}$ depth. Meiofauna was extracted from the sample by Robert P. Higgins. The single glycerin-impregnated specimen was mounted by Reinhardt M. Kristensen on a glass slide with a cover slide and sealed with Glyceel.

Photomicrographs presented in this study were taken on a Zeiss Ultraphot III microscope or an Olympus BX51 microscope; both equipped with phase contrast $(\mathrm{PhC})$ and differential interference contrast (DIC) optics. The drawings were made with the aid of drawing tube mounted on an Olympus BX51 microscope with DIC optics. Figures were assembled using the software package Corel Draw Graphics Suite X6.

The terminology generally follows Hansen et al. (2016), Fontoura et al. (2017) and Anguas-Escalante et al. (2020).

\section{Abbreviations for morphological terms used in figures}

$\begin{array}{ll}\text { af } & =\text { frontal ala } \\ \text { an } & =\text { anus } \\ \text { bt } & =\text { buccal tube } \\ \text { ca } & =\text { caudal alae } \\ \text { cs } & =\text { cuticular stripes } \\ \mathrm{cE} & =\text { cirrus E } \\ \text { ec } & =\text { external cirrus } \\ \text { ed } & =\text { external digit } \\ \text { fo } & =\text { folium } \\ \text { go } & =\text { gonopore } \\ \text { gp } & =\text { genital papilla } \\ \text { gs } & =\text { genital stoup } \\ \text { gu } & =\text { gut } \\ \text { ic } & =\text { internal cirrus } \\ \text { la1 } & =\text { antero-lateral ala } \\ \text { la2 } & =\text { medio-lateral ala } \\ \text { la3 } & =\text { postero-lateral ala } \\ \text { lc } & =\text { lateral cirrus } \\ \text { le1-le3 } & =\text { leg 1-leg } 3 \\ \text { mc } & =\text { median cirrus } \\ \text { mo } & =\text { mouth cone } \\ \text { ov } & =\text { ovary }\end{array}$




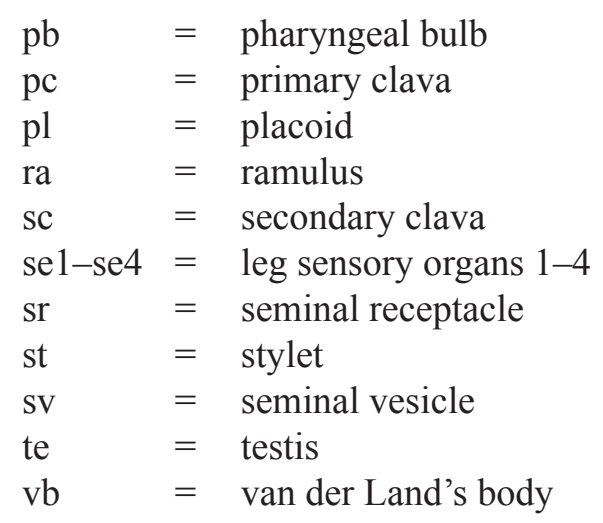

\section{Results}

Phylum Tardigrada Doyère, 1840

Class Heterotardigrada Marcus, 1927

Order Arthrotardigrada Marcus, 1927

Family Halechiniscidae Thulin, 1928 (emended by Fujimoto et al. 2017)

Subfamily Florarctinae Renaud-Mornant, 1982 (emended by Kristensen 1984)

\section{Amended diagnosis}

Halechiniscidae with cuticular aliform expansions. Caudal alae always present in adults. Complete set of cephalic cirri and two sets of clavae. Secondary clavae occurring as flat sacs or as dome-shaped or spherical papillae. Four digits with claws present in adults. External digits supported by hook-shaped peduncles. External claw with calcar and with internal avicularium or small notch. Internal claw with accessory spine, calcar present or absent. Females with two seminal receptacles, each consisting of a spheroid vesicle and an S-shaped genital duct.

\section{Type genus}

Florarctus Delamare-Deboutteville \& Renaud-Mornant, 1965.

Genus Higginsarctus gen. nov. urn:1sid:zoobank.org:act:B191A524-2C5F-4DBD-93BA-7DC1ADB82CC7

\section{Type species}

Higginsarctus signeae gen. et sp. nov.

\section{Diagnosis}

A genus of Florarctinae characterized by large, rigid and backwards bending primary clavae (shared with Ligiarctus) supported by strong internal cuticular structures at their bases. Secondary clavae occurring as papillae (dome-shaped or spherical) or as flat sacs (round, rectangular or bilobed). Frontal ala, six lateral alae and a single caudal ala present. The proximal part of the alae (except for the frontal) internally supported by procuticle which sends out branching processes (ramuli) into the distal part of the alae. External claws with calcars and with small internal notches; internal claws with accessory spines and small internal notches.

\section{Etymology}

The new genus is dedicated to Dr Robert P. Higgins for his contributions to meiofauna research. Higgins + arctus (latinised Greek word), meaning Higgins's bear. 
Table 1. Differential table of major morphological characters in species of Higginsarctus gen. nov.

\begin{tabular}{|c|c|c|c|c|c|c|}
\hline & $\begin{array}{c}H . \text { signeae } \\
\text { gen. et sp. nov. }\end{array}$ & $\begin{array}{c}H . \text { shintai } \\
\text { gen. et sp. nov. }\end{array}$ & $\begin{array}{c}\text { H. lassei } \\
\text { gen. et sp. nov. }\end{array}$ & $\begin{array}{c}H . \text { martini } \\
\text { gen. et sp. nov. }\end{array}$ & $\begin{array}{c}\text { H. laurae } \\
\text { gen. et sp. nov. }\end{array}$ & $\begin{array}{l}\text { H. alatus gen. et } \\
\text { comb. nov. }\end{array}$ \\
\hline Secondary clava & $\begin{array}{l}\text { Flat, rectangular } \\
\text { with sligthly } \\
\text { protruding } \\
\text { contours }\end{array}$ & $\begin{array}{l}\text { Flat, comma- } \\
\text { shaped }\end{array}$ & Flat, oval & $\begin{array}{l}\text { Ovoid, dome- } \\
\text { shaped }\end{array}$ & Spherical & Flat, bilobed \\
\hline Antero-lateral ala & $\begin{array}{l}\text { Unilobed without } \\
\text { indentation }\end{array}$ & $\begin{array}{l}\text { Unilobed without } \\
\text { indentation }\end{array}$ & $\begin{array}{l}\text { Unilobed } \\
\text { without } \\
\text { indentation }\end{array}$ & $\begin{array}{l}\text { Bilobed with } \\
\text { medial pointed } \\
\text { indentation }\end{array}$ & $\begin{array}{l}\text { Trilobed with pair } \\
\text { of medial pointed } \\
\text { indentations }\end{array}$ & $\begin{array}{l}\text { Unilobed without } \\
\text { indentation }\end{array}$ \\
\hline Medio-lateral ala & $\begin{array}{l}\text { Unilobed without } \\
\text { indentation }\end{array}$ & $\begin{array}{l}\text { Unilobed without } \\
\text { indentation }\end{array}$ & $\begin{array}{l}\text { Bilobed with } \\
\text { medial pointed } \\
\text { indentation }\end{array}$ & $\begin{array}{l}\text { Bilobed with } \\
\text { medial pointed } \\
\text { indentation }\end{array}$ & $\begin{array}{l}\text { Bilobed with } \\
\text { medial pointed } \\
\text { indentation }\end{array}$ & $\begin{array}{l}\text { Unilobed without } \\
\text { indentation }\end{array}$ \\
\hline $\begin{array}{l}\text { Postero-lateral } \\
\text { ala }\end{array}$ & $\begin{array}{l}\text { Bilobed, } \\
\text { rectangular with } \\
\text { medial arched } \\
\text { indentation }\end{array}$ & $\begin{array}{l}\text { Bilobed with } \\
\text { medial pointed } \\
\text { indentation }\end{array}$ & $\begin{array}{l}\text { Bilobed with } \\
\text { medial arched } \\
\text { indentation }\end{array}$ & $\begin{array}{l}\text { Trilobed with } \\
\text { anterior pointed } \\
\text { indentation and } \\
\text { posterior arched } \\
\text { indentation }\end{array}$ & $\begin{array}{l}\text { Bilobed with } \\
\text { medial pointed } \\
\text { indentation }\end{array}$ & $\begin{array}{l}\text { Bilobed with } \\
\text { medial arched } \\
\text { indentation }\end{array}$ \\
\hline Caudal ala & $\begin{array}{l}\text { Quadrilobed, } \\
\text { rectangular } \\
\text { with } 3 \text { arched } \\
\text { indentations }\end{array}$ & $\begin{array}{l}\text { Quadrilobed, } \\
\text { rectangular } \\
\text { with } 3 \text { arched } \\
\text { indentations }\end{array}$ & $\begin{array}{l}\text { Quadrilobed, } \\
\text { rectangular } \\
\text { with } 3 \text { arched } \\
\text { indentations }\end{array}$ & $\begin{array}{l}\text { Quadrilobed, } \\
\text { round with } \\
3 \text { arched } \\
\text { indentations }\end{array}$ & $\begin{array}{l}\text { Bilobed, round } \\
\text { with medial } \\
\text { pointed indentation }\end{array}$ & $\begin{array}{l}\text { Bilobed, } \\
\text { rectangular with } \\
\text { medial arched } \\
\text { indentation }\end{array}$ \\
\hline $\begin{array}{l}\text { Leg sensory } \\
\text { organs I-III }\end{array}$ & Similar in length & Similar in length & Similar in length & Similar in length & Similar in length & $\begin{array}{l}\text { Highly different } \\
\text { in length }\end{array}$ \\
\hline Genital stoup & Present & - & Present & Present & - & Present \\
\hline Genital papilla & Absent & Absent & Absent & Absent & Absent & Present \\
\hline Folia & Present & Absent & Absent & Absent & Present & Absent \\
\hline
\end{tabular}

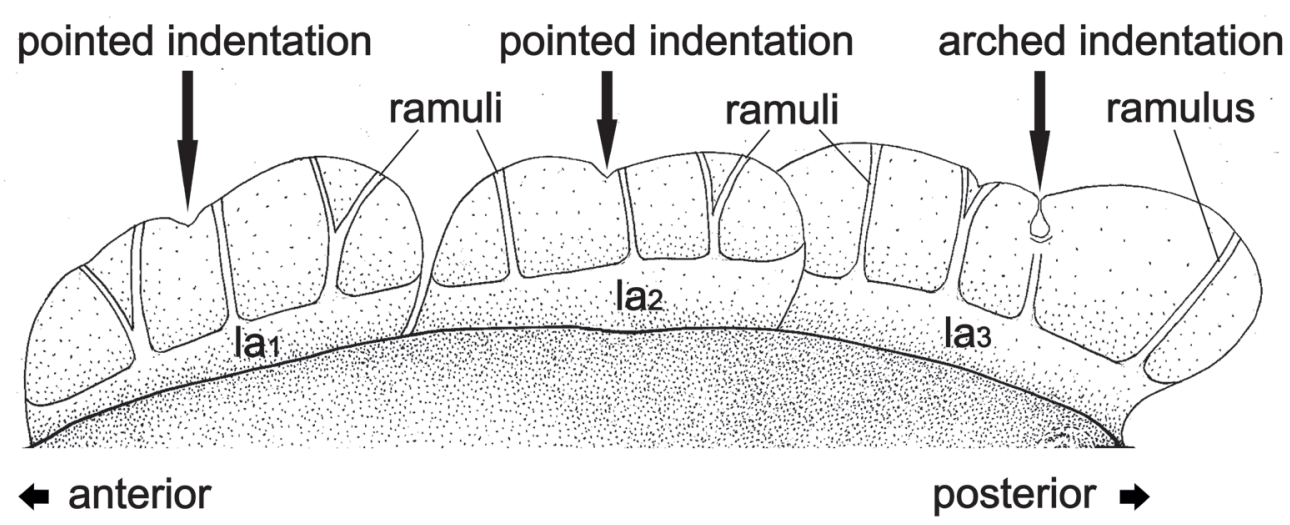

\section{$25 \mu \mathrm{m}$}

Fig. 1. General features of the lateral alae of Higginsarctus gen. nov. The procuticle sends out branches (ramuli) to the edge of the alae. Drawing by Stine B. Elle. 


\section{Remarks}

Higginsarctus gen. nov. shares with species of Florarctus, Ligiarctus and Wingstrandarctus the presence of alae, the shape of the cephalic cirri and fourth leg sense organ, the shape of the seminal receptacles, and the presence of internal hook-shaped peduncles. The very characteristic primary clavae, being large, rigid and backward bending, are shared only with Ligiarctus. It is very apparent that this new genus belongs to Florarctinae, perhaps being closest related to Ligiarctus. However, three characters of Higginsarctus gen. nov. set the genus apart from Florarctus, Ligiarctus and Wingstrandarctus, namely the number of lateral alae, the branching processes of procuticle reaching the distal part of the alae, and the presence of a small internal notch both on external and internal claws.

The term 'caestus'(from Latin = 'gauntlet'), originally suggested by Renaud-Mornant (1987), has been generally adopted as a term for the supporting procuticle of the alae in species of Florarctus (Fontoura et al. 2017; Hansen \& Kristensen 2020). While the procuticle of the alae in species of Florarctus generally forms proximal lobate processes, it is much different in species of Higginsarctus gen. nov. where the entire proximal half of the alae are supported by a procuticle which sends out branching processes into the distal part of the alae. It is therefore suggested to refer to this special configuration of the supporting structure in the alae of Higginsarctus gen. nov. as 'ramuli' (plural form of 'ramulus' (Latin) meaning 'a small branch').

The six species of Higginsarctus gen. nov. described below differ conspicuously in the morphology of the secondary clava. Further distinguishing characters include differences in alae morphology, genital features and ventral cuticular structures (Table 1).

As in Florarctus and Wingstrandarctus, the distal margin of the lateral and caudal alae in species of Higginsarctus gen. nov. are characterised by small or larger indentations. Although being essential to an accurate description of alae morphology of each species, previous studies have not discriminated between types of indentations. Having studied numerous species of Florarctinae we believe that two morphological distinct types of indentations can be recognised, namely the 'pointed' type (Fig. 1) and the 'arched' type (Fig. 1). Consequently, the two types are discriminated in the species descriptions below. We also suggest considering both types in all future descriptions of species belonging to Florarctinae.

A new genital structure not observed previously in tardigrades is recognised in 4 out of 6 species. It is situated immediately posterior to the gonopore and will be referred to as the 'genital stoup' as it resembles the shape of the holy water holder (Figs 2, 4E). Further investigation is needed to determine the exact function of this structure but it likely plays a role in either copulation or oviposition by facilitating the detention of spermatids/spermatozoa. The presence or absence of a genital stoup in Higginsarctus shintai gen. et sp. nov. and H. laurae gen. et sp. nov. cannot be determined with certainty in the present study. Thus, it might be confirmed as an apomorphy of the new genus, pending a closer study of new material.

A special kind of leaf-like structures are present on the ventral cuticle in the two species Higginsarctus signeae gen et sp. nov. (Fig. 2) and H. laurae gen. et sp. nov. (Figs 14, 16C). Such structures have not been discussed or named previously in Florarctinae although they are present in Florarctus heimi Delamare-Deboutteville \& Renaud-Mornant, 1965 (see Gąsiorek et al. 2021: fig. 6), and will tentatively be referred to as 'folia' (plural form of 'folium' (Latin), meaning a thin leaf-like structure or lamella, a leaf, especially a thin leaf or plate (geometry)).

Higginsarctus signeae gen. et sp. nov. urn:1sid:zoobank.org:act:4F3D0D8B-BC13-4B98-9DD5-A5DA3A3BD817

Figs $2-7$

Florarctinae nov. gen. 1 et nov. sp. 1 - Hansen et al. 2001. - Hansen 2005. 
Diagnosis (characters uniquely defining the taxon are written in bold)

Characterized by flat, rectangular secondary clavae with slightly protruding contours. Each clava inserted on a small elevation of the ventral cuticle. Unilobed, rectangular antero-lateral alae with weakly undulating distal margins without indentations. Unilobed, rectangular medio-lateral alae with weakly undulating distal margins without indentations. Antero-lateral alae and medio-lateral alae similar in size. Bilobed postero-lateral alae with a medial arched identation. Postero-lateral alae larger than antero-lateral alae and medio-lateral alae. Quadrilobed, rectangular caudal ala with 3 arched indentations, 1 medial and 2 lateral. Lateral lobes of the caudal ala nearly rectangular. Leg sense organs I-III with similar length. Genital stoup present. Anus inserted on ventral folium.

\title{
Etymology
}

The new species is dedicated to Signe G. Hansen, the daughter of the first author.

\section{Material examined}

Holotype

FAROE ISLANDS • 9 ; North Atlantic Ocean, Faroe Bank; 61 ${ }^{\circ} 23.18^{\prime} \mathrm{N}, 08^{\circ} 35.13^{\prime} \mathrm{W}$; depth $273 \mathrm{~m}$; 1 Apr. 1992; R.M. Kristensen leg.; BIOFAR Station 788; coarse shell gravel; NHMD-293899.

\author{
Allotype \\ FAROE ISLANDS • ${ }^{\top}$; same collection data as for holotype; $61^{\circ} 00^{\prime} \mathrm{N}, 08^{\circ} 13^{\prime} \mathrm{W}$; depth $120 \mathrm{~m}$; 19 Sep. \\ 1998; R.M. Kristensen leg.; BIOFAR Station 2013; coarse shell gravel; NHMD-293900.

\section{Paratypes} \\ FAROE ISLANDS • 1 q; same collection data as for holotype; $61^{\circ} 12.33^{\prime} \mathrm{N}, 08^{\circ} 28.23^{\prime} \mathrm{W}$; depth $148 \mathrm{~m}$; \\ 1 Apr. 1992; R.M. Kristensen leg.; BIOFAR Station 786; fine shell sand; NHMD-293898 • 1 q; same \\ collection data as for holotype; $61^{\circ} 00^{\prime}$ N, $08^{\circ} 13^{\prime}$ W; depth 120 m; 19 Sep. 1998; R.M. Kristensen leg.; \\ BIOFAR Station 2013; coarse shell gravel; NHMD-293901•1 $\odot$; same collection data as for preceding; \\ used for SEM; NHMD-293902.
}

\section{Type locality}

Faroe Bank, North Atlantic Ocean (between $61^{\circ} 00^{\prime} \mathrm{N}, 08^{\circ} 13^{\prime} \mathrm{W}$ and $61^{\circ} 23.18^{\prime} \mathrm{N}, 08^{\circ} 35.13^{\prime} \mathrm{W}$; depth range, $120-273 \mathrm{~m})$.

\section{Description}

HaBitus. The holotypic female (Figs 2, 3B-E) is $147 \mu \mathrm{m}$ long from the anterior margin of the head to the posterior margin of the body. The body is ovoid, being broadest $(94 \mu \mathrm{m})$ at the level between the second and third pair of legs. It is highly convex dorsally, and flattened ventrally. The anterior margin of the head taper off, into a thin membrane-like structure (the ala anterior; van der Land 1968), which is different from the alae of the body. It is here referred to as the frontal ala (Fig. 2). The dorsal cuticle has four transverse inter-segmental folds: one anterior to the first pair of legs, two between the first and second pair of legs and one between the second and third pair of legs. The SEM studies of a paratypic female shows two large pores mid-dorsally, at the level of the third pair of legs (Fig. 5D). A deep longitudinal furrow extends mid-dorsally from the insertion of the caudal ala and halfway to the dorsal pores. Also only visible by SEM (in LM the dorsal cuticle appears smooth with small pillars inside the epicuticle), the dorsal cuticle is remarkably sculptured with numerous small knob-like structures of two different types: one type which is organized in rosettes of five, and another type which is larger, with a more spongy appearance, occurring separately. The two types are evenly distributed in the cuticle (Fig. 5E). This kind of dorsal cuticular structure has never been observed in any tardigrade species before. The ventral cuticle is perfectly smooth with small pillars inside the epicuticle. 


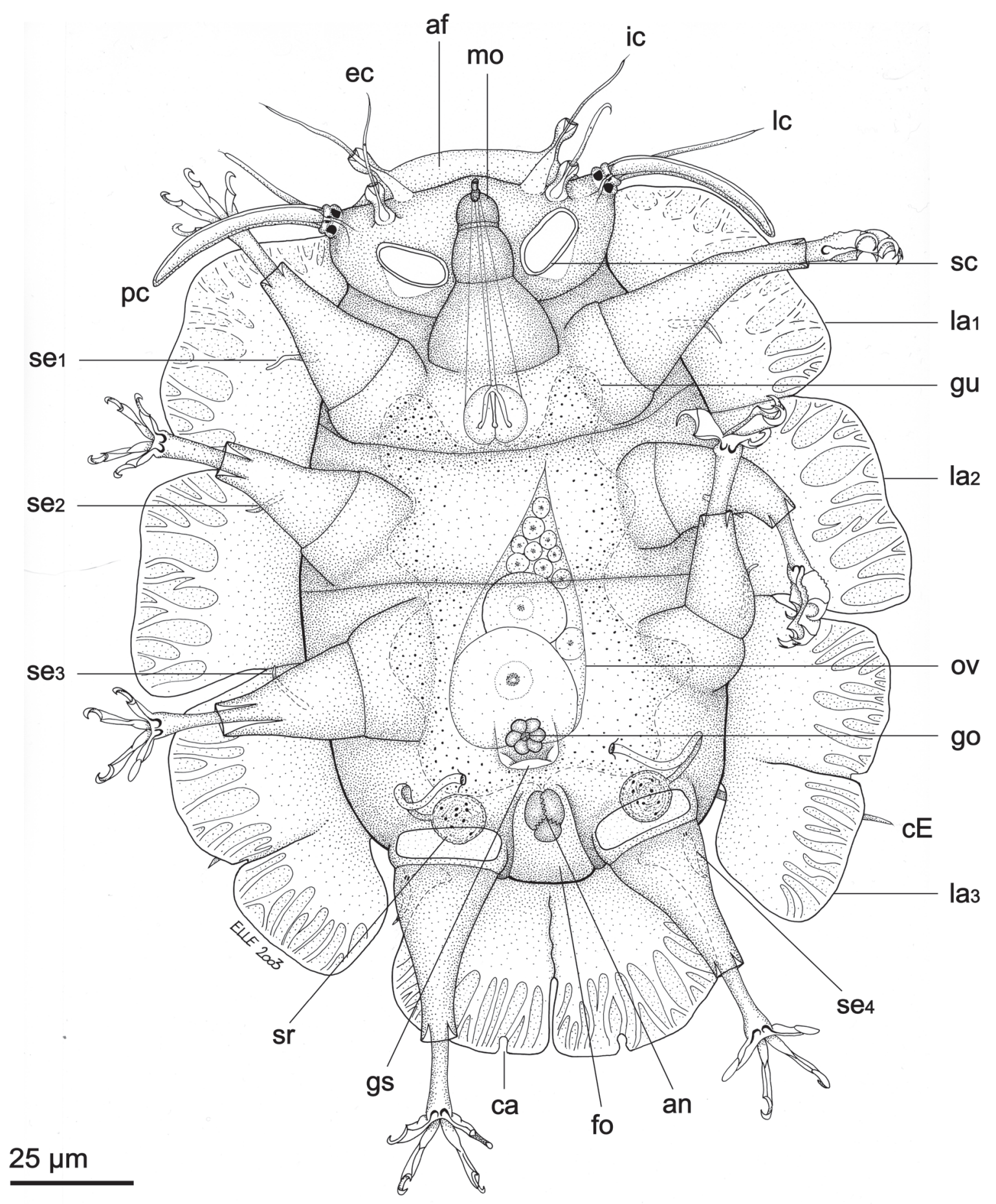

Fig. 2. Higginsarctus signeae gen. et sp. nov. Ventral overview. Holotype, $q$ (NHMD-293899). Abbreviations: see Material and methods. Drawing by Stine B. Elle. 

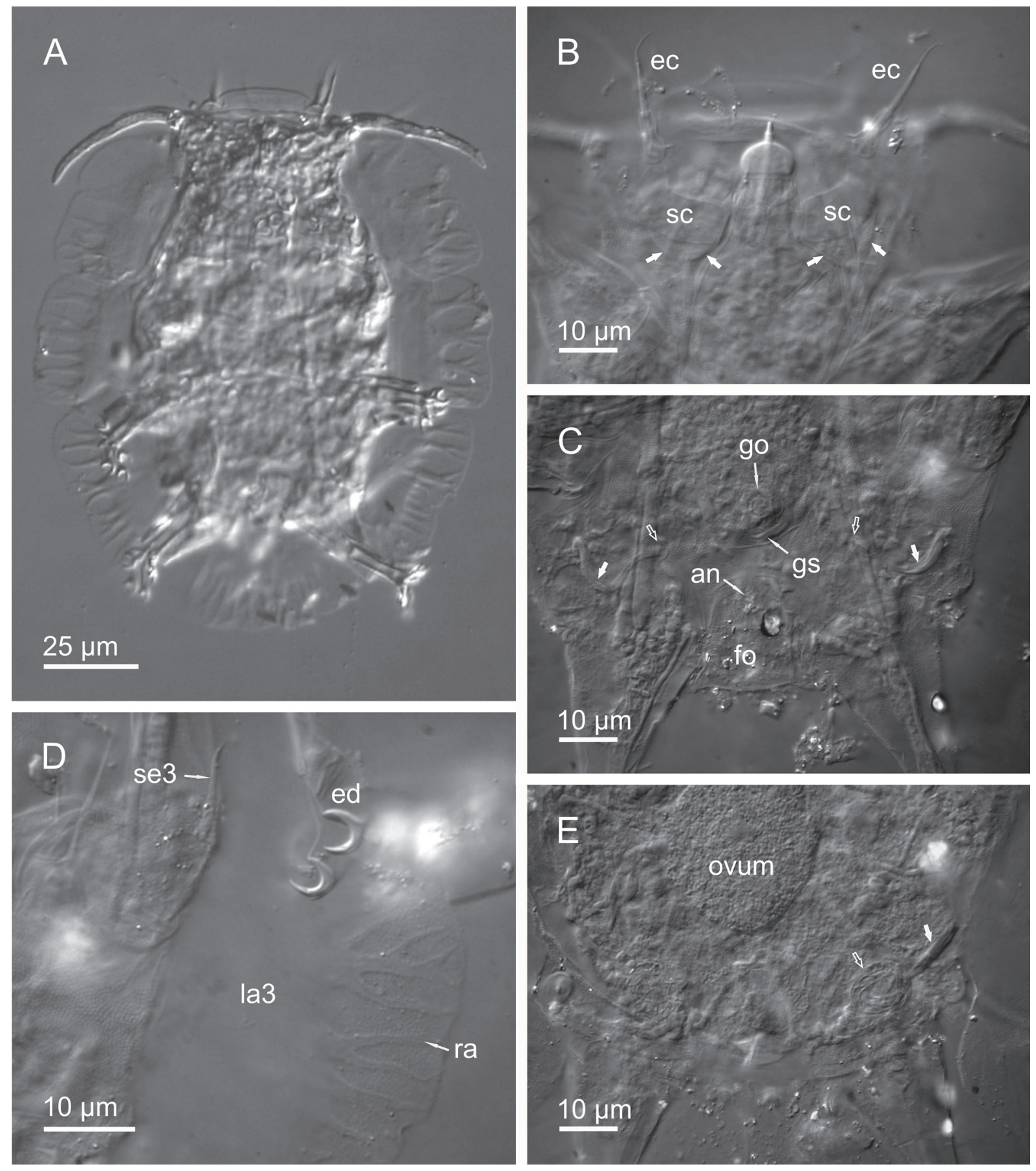

Fig. 3. DIC-micrographs of Higginsarctus signeae gen. et sp. nov. A. Paratype, $q$ (NHMD-293898), overview. B-E. Holotype, of (NHMD-293899). B. Close up on the head, ventral view showing the secondary clavae and the very refractive cupola of the mouth cone. White solid arrows indicate elevation of the cuticle associated with the secondary clavae. C, E. Optical sections of the caudal end, showing gonopore, genital stoup, duct openings (white hollow arrows), ducts of the seminal receptacles (white solid arrows) and the ventral folium with anus (C), and ovum, duct of the seminal receptacles (white solid arrow) and vesicle of seminal receptacles (white hollow arrow) (E). D. Close up on the procuticular branches (ramuli) in the ala, the internal and external claw of leg II and the sense organ of leg III. Abbreviations: see Material and methods. 
AlAE. Eight alae, which are all clearly separated from each other, are present (Fig. 2): frontal ala, a pair of antero-lateral alae, a pair of medio-lateral alae, a pair of postero-lateral alae and a single caudal ala (see also paratypes Figs 4A, 5A). The antero-lateral alae and medio-lateral alae are all similar in size and shape being unilobed and rectangular with weakly undulating distal margins without indentations. The postero-lateral alae each have a medial arched indentation in the distal margin, dividing the ala into two lobes of equal size. The caudal ala is narrowed at the insertion on the body and has an overall rectangular shape with a deep medial, arched indentation and a pair of lateral, arched indentations dividing the ala into four lobes. The medial lobes are small and rounded whereas the lateral lobes are larger and more rectangular. The pillars in the alae are visible as closely spaced dots. The proximal halve of the lateral and caudal alae is internally supported by continuous procuticle which sends out branching processes (ramuli) into the distal halve of the alae. The branching processes all start at the same level, thus creating a clear dividing line between continuous procuticle and branching procuticle, giving the alae a very characteristic appearance (Figs 2, 3D).

Sensory organs. The head is well defined from the body by a constriction and a complete set of sense organs is present. All the cephalic cirri consist of an hourglass-shaped scapus, a long tubular portion and a protruding flagellum. As in most other species of Florarctinae the scapus of each cirrus appears somewhat outsized, enveloping the internal sensory structures rather than lining them. The internal cirri $(35 \mu \mathrm{m})$ emerge from the frontal ala at the anterior margin of the head. The external cirri $(29 \mu \mathrm{m})$ are inserted ventrally and the median cirrus mid-dorsally. The primary clava is relatively long $(43 \mu \mathrm{m})$, slightly curved and non-flexible (Fig. 2 and paratypes Figs 3A, 7A). A van der Land's body is visible inside its base. Primary clava and lateral cirrus $(34 \mu \mathrm{m})$ arise on the same cirrophore, and a common membrane (extended margin of cirrophore) surrounds the base of primary clava and lateral cirrus. A very large and thick cuticular ring supports the cirrophore internally, and is probably functioning as an anchor of the primary clava (see paratype Fig. 7C). The secondary clavae are large, rectangular flat sacs $(8 \mu \mathrm{m} \times 15 \mu \mathrm{m})$ flanking the mouth cone (Fig. 3B). Each clava is inserted on a small elevation of the ventral cuticle. In SEM of a paratypic female, the contours of the secondary clavae are recognizable, protruding slightly from the ventral cuticle (Fig. 4B). The leg I sense organ $(11 \mu \mathrm{m})$ is an unsegmented spine with a slightly swollen base and a terminal tube. The sense organs of leg II $(8 \mu \mathrm{m})$ and III $(8 \mu \mathrm{m})$ are unsegmented tapering spines. The fourth leg sense organ $(12 \mu \mathrm{m})$ is an elongate papilla with a basal van der Land's body and a terminal pore. The cirrus E $(46 \mu \mathrm{m})$ has a prominent cirrophorus, scapus and a long tapering flagellum. The scapus has a highly complex composition. The outer lining is composed of small pellets organized in regular rings. At least 33 rings are recognisable by LM and SEM, however the pellets are recognizable as separate units, only by using SEM-technique (Fig. 4F-G).

Legs, Digits AND Claws. The legs consist of coxa, femur, tibia and tarsus as found in all species of Florarctinae. A rectangular folium-like structure is weakly evident ventrally on each coxa of leg pair IV (Fig. 2). Whether or not this is a true folium awaits the analysis of additional material. The external digits are supported by internal hook-shaped peduncles. The external claw is simple and with a calcar. The internal claw has an accessory spine, but no calcar. All the claws are of the same size, however the external claws are thicker basally and the internal claws have an almost straight portion dorsally (Fig. 3D and paratype Fig. 5B-C). An internal partition is evident as a small notch in each claw, dividing the claw in a basal portion and a distal portion (Fig. 3D and paratype Fig. 7D).

BUCCO-PHARYNGEAL APPARATUS. The mouth cone is large and consists of three parts; a large basal cone, a middle telescopic cylinder and a terminal, very refractive cupola, through which the distal part of the stylet sheaths, protrude (Fig. 3B and paratype Fig. 7B). The buccal tube is $41 \mu \mathrm{m}$ long and thin and has a small refractive bulb anterior to the placoids. The stylets are $44 \mu \mathrm{m}$ long and very thin, each with a small furca (Fig. 2 and paratype Fig. 7C). The placoids are short, thick and strongly curved. Each placoid has a droplet-shaped terminal swelling (Fig. 2 and paratype Fig. 7C). 

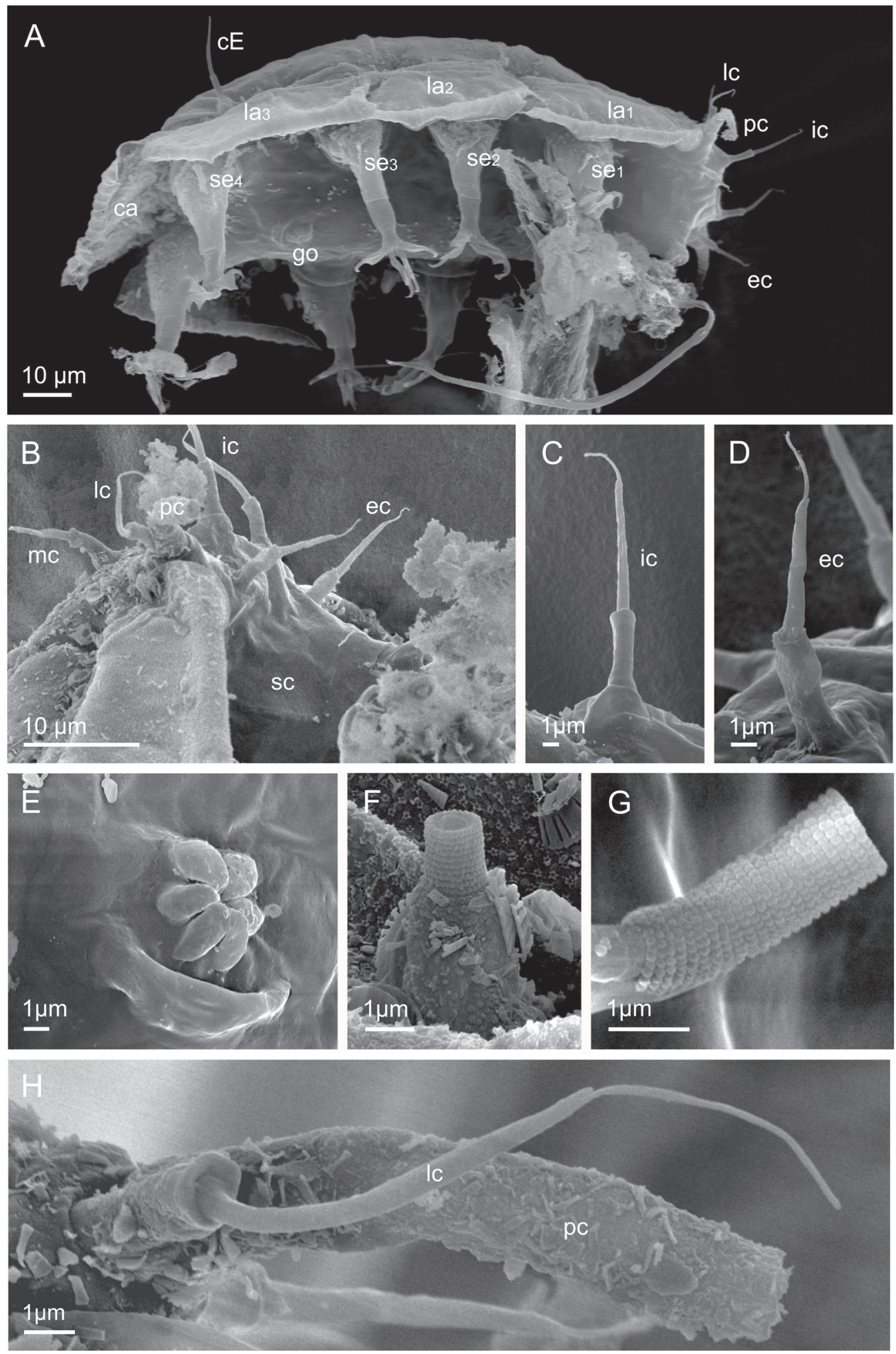

Fig. 4. SEM-micrographs of Higginsarctus signeae gen. et sp. nov., paratype, $q$ (NHMD-293902). A. Ventro-lateral overview. B. Close up on the head, lateral view showing cephalic cirri and secondary clava. C. Internal cirrus. D. External cirrus. E. Gonopore and genital stoup. F-G. Scapus of cirrus E broken in two (note the unique small papillae of scapus). H. Primary clavae (broken) and lateral cirrus. Abbreviations: see Material and methods. 

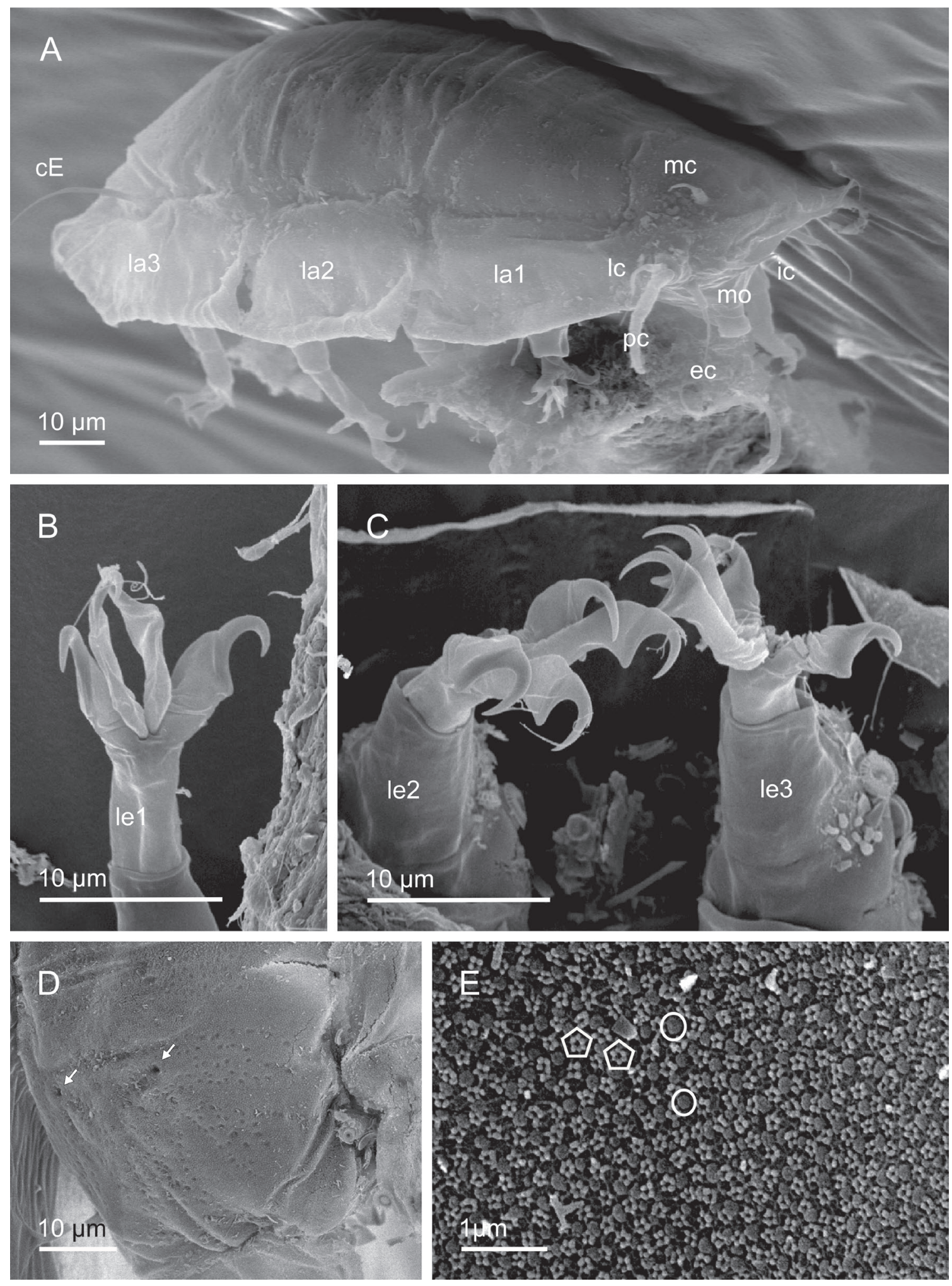

Fig 5. SEM-micrographs of Higginsarctus signeae gen. et sp. nov., paratype, $q$ (NHMD-293902). A. Dorso-lateral overview. B. Digits and claws of leg I. C. Digits and claws of leg II and leg III. D. Caudal end, dorsal view. Arrows indicate the large dorsal pores. E. Close up on the sculpture of the dorsal cuticle. The small knob-like structures arranged in rosettes are indicated by white polygons. The larger knob-like structures are indicated by white circles. Abbreviations: see Material and methods. 


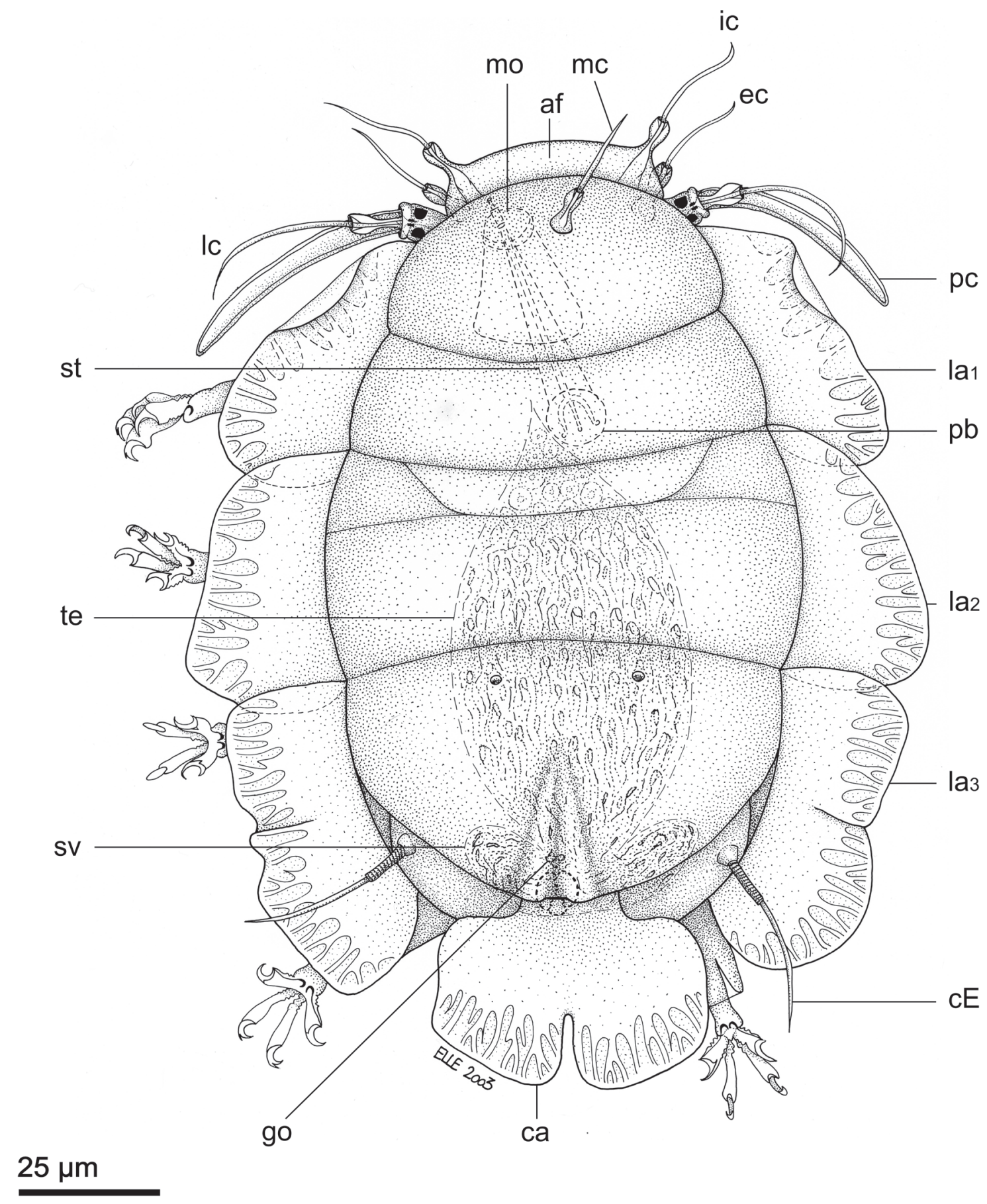

Fig. 6. Higginsarctus signeae gen. et sp. nov., allotype, ठิ (NHMD-293900). Dorsal overview. Abbreviations: see Material and methods. Drawing by Stine B. Elle. 

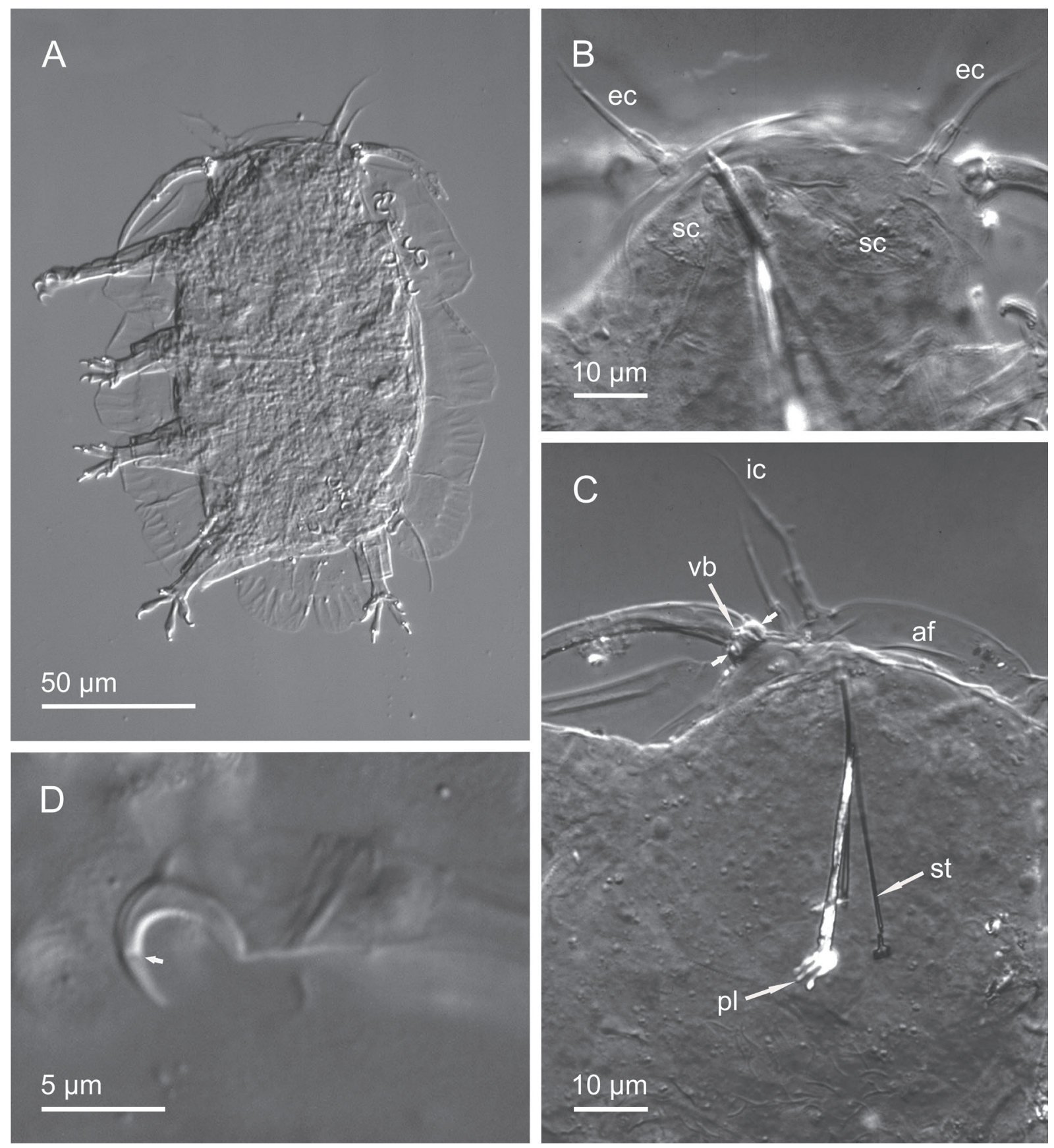

Fig. 7. DIC-micrographs of Higginsarctus signeae gen. et sp. nov., allotype, § (NHMD-293900). A. Overview. B. Close up on the head, ventral view showing the external cirri, secondary clavae and the very refractive cupola of the mouth cone. Note the presence of bacteria underneath the secondary clavae. C. Close up on the bucco-pharyngeal apparatus and the insertion of the primary clava with large refractive structures inside the base (white solid arrows) and van der Land's body. D. Close up on the external claw of leg I, with evident internal notch (white solid arrow). Abbreviations: see Material and methods. 
ReProductive SYSTEM. Consists of a single ovary bearing numerous small oocytes and three larger ova. The ovary is $58 \mu \mathrm{m}$ long and is attached dorsally, at the level of the second pair of legs. The gonopore consists of a rosette with six large cells. Posterior to the rosette, the cuticle forms what appears in LM to be a broad fold. The SEM studies of a paratypic female shows that the cuticle is in fact forming a kind of basin or cup-like structure (Fig. 4E). It is here referred to as a 'genital stoup'. The two cuticular seminal receptacles each consist of a spheroid vesicle and an S-shaped genital duct (Figs 2, 3C, E). The cuticle is slightly elevated at each duct opening but does not form a true papilla. The vesicles are filled with spermatozoa. The anus is situated on a large rectangular folium (Figs 2, 3C), and is closed by a threelobed cuticular system consisting of two large lateral lobes and a smaller posterior lobe.

Allotypic male (Figs 6-7)

No strong secondary sexual dimorphism is observed in Higginsarctus signeae gen. et sp. nov. The male is a little smaller $(134 \mu \mathrm{m})$ than the female, and the primary clavae a little longer $(46 \mu \mathrm{m})$. Also the secondary clavae have a slightly different shape, being more oval than rectangular (Fig. 7B). Bacterial vesicles are present just beneath the secondary clavae. The male gonopore is a small triangular papilla with two large pores (openings of the gonoducts), and is situated very close to the anus. The testis is large $(87 \mu \mathrm{m})$, extending to the pharyngeal bulb, at the level of the first pair of legs. Two small lateral seminal vesicles are present.

\section{Paratypes}

The paratype NHMD-293898 is a juvenile female without a fully developed rosette gonopore. It measures $113 \mu \mathrm{m}$ in body length, $66 \mu \mathrm{m}$ in width and the primary clavae are $42 \mu \mathrm{m}$. The other paratype NHMD-29902 is a fully mature female with a body length of $142 \mu \mathrm{m}$, body width of $90 \mu \mathrm{m}$ and the primary clavae are $49 \mu \mathrm{m}$.

\section{Ecology and distribution}

Known only from the type locality.

Higginsarctus shintai gen. et sp. nov. urn:1sid:zoobank.org:act:599082EE-9564-47C0-9CF9-A1EFD5F71F31

Figs $8-9$

Diagnosis (characters uniquely defining the taxon are written in bold)

Characterized by flat, comma-shaped secondary clavae. Unilobed, rectangular antero-lateral alae with weakly undulating distal margins without indentations. Unilobed, rectangular medio-lateral alae with weakly undulating distal margins without indentations. Antero-lateral alae and medio-lateral alae similar in size. Bilobed postero-lateral alae with medial pointed identation. Postero-lateral alae larger than antero-lateral alae and medio-lateral alae. Quadrilobed, rectangular caudal ala with 3 arched indentations, 1 medial and 2 lateral. Medial lobes of caudal ala small and rounded, lateral lobes larger, nearly rectangular. Leg sense organs I-III with similar length.

\section{Etymology}

The new species is dedicated to Dr Shinta Fujimoto for his contributions to tardigradology.

\section{Material examined}

\section{Holotype}

FRANCE - + ; North Atlantic Ocean, English Channel, Bay of Morlaix, Roscoff; $48^{\circ} 43^{\prime} \mathrm{N}, 03^{\circ} 54^{\prime} \mathrm{W}$; depth 20-30 m; 15 Mar. 1982; R.M. Kristensen leg.; Dentalium sand; NHMD-293904. 


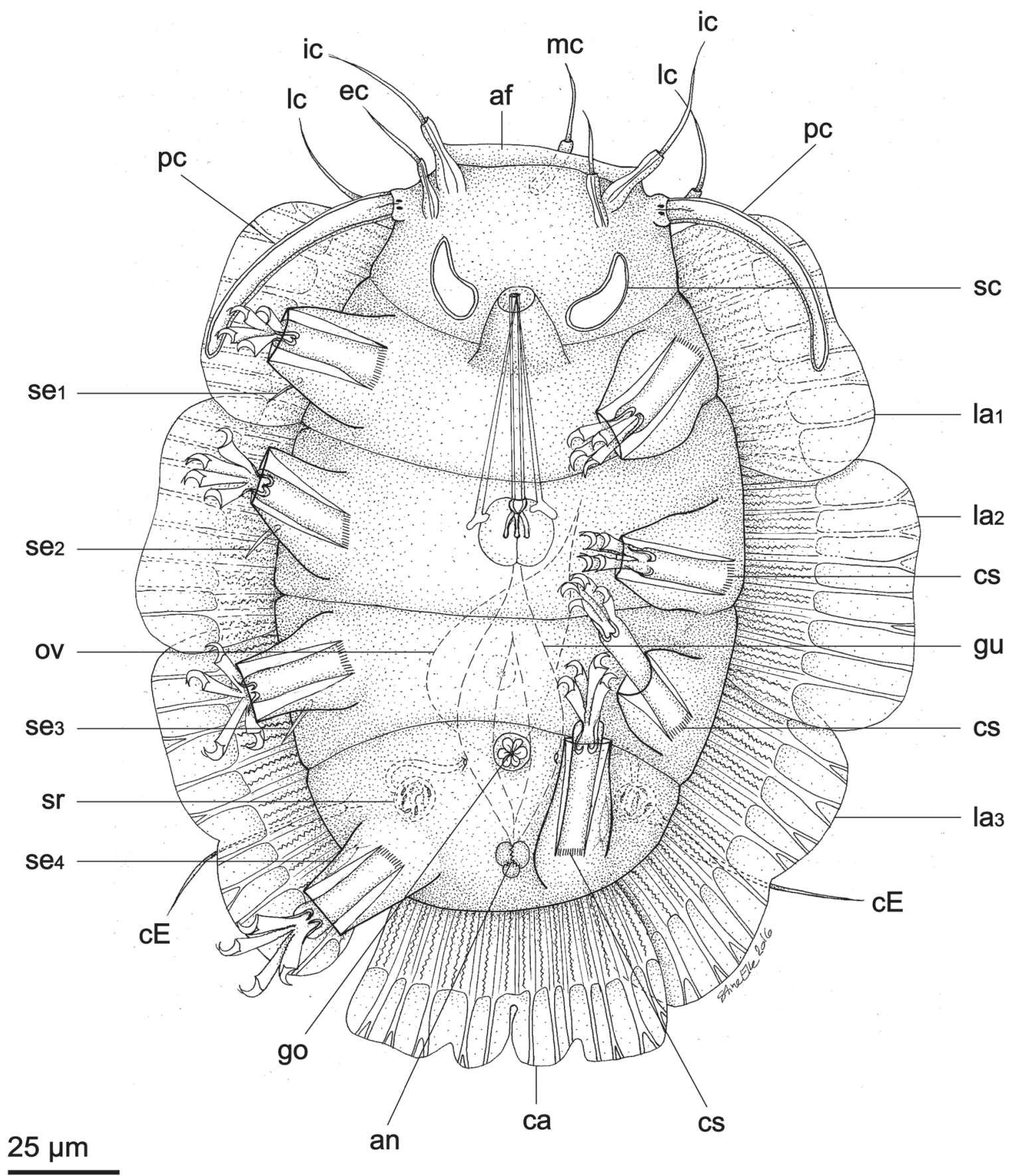

Fig. 8. Higginsarctus shintai gen. et sp. nov., holotype, ㅇ (NHMD-293904). Ventral overview. Abbreviations: see Material and methods. Drawing by Stine B. Elle. 


\section{Description}

Habitus. The holotypic female (Figs 8-9) is $173 \mu \mathrm{m}$ long from the anterior margin of the head to the posterior margin of the body. The body is ovoid, being broadest $(106 \mu \mathrm{m})$ at the level between the second and third pair of legs. The dorsal cuticle has three transverse inter-segmental folds: one anterior to the first pair of legs, one between the first and second pair of legs and one between the second and third pair of legs.

AlaE. Typical for the genus, eight alae, which are all clearly separated from each other, are present: frontal ala, a pair of antero-lateral alae, a pair of medio-lateral alae, a pair of postero-lateral alae and a single caudal ala (Fig. 8). Both the lateral and caudal alae appear corrugated, having transverse ridges perfectly parallel to each other. The antero-lateral alae and medio-lateral alae are all similar in size and shape being unilobed and rectangular with weakly undulating distal margins without indentations. The postero-lateral alae each have a medial pointed indentation, dividing the ala into two lobes of equal size. The caudal ala has an overall rectangular shape with a deep medial, arched indentation and
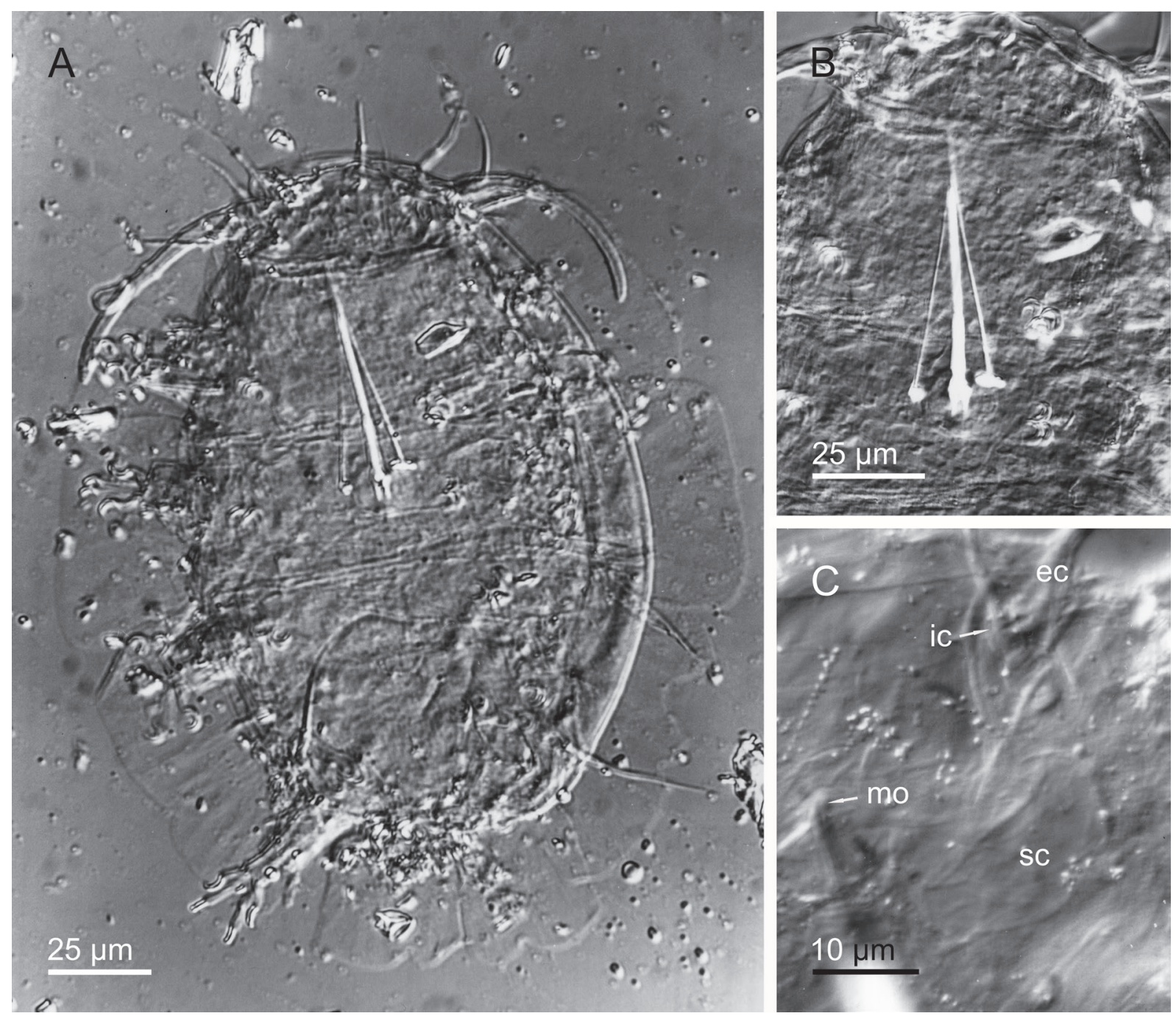

Fig. 9. DIC-micrographs of Higginsarctus shintai gen. et sp. nov., holotype, $q$ (NHMD-293904). A. Overview. B. Bucco-pharyngeal apparatus. C. Close up on the head, ventral view showing the secondary clava, internal and external cirri. Abbreviations: see Material and methods. 
a pair of lateral, arched indentations dividing the ala into four lobes. The medial lobes are small and rounded whereas the lateral lobes are larger and nearly rectangular. As in all species of the new genus, the proximal halve of the lateral and caudal alae is internally supported by continuous procuticle which sends out branching processes (ramuli) into the distal halve of the alae.

Sensory organs. The head is not well defined from the body and a complete set of sense organs is present. All the cephalic cirri consist of an hourglass-shaped scapus, a long tubular portion and a protruding flagellum. As in most other species of Florarctinae the scapus of each cirrus appears somewhat outsized, enveloping the internal sensory structures rather than lining them. The internal cirri $(51 \mu \mathrm{m})$ emerge from the frontal ala at the anterior margin of the head. The external cirri $(28 \mu \mathrm{m})$ are inserted ventrally and the median cirrus mid-dorsally. Typical for the genus, the primary clava $(57 \mu \mathrm{m})$ is slightly curved and non-flexible (Fig. 9A). A van der Land's body is visible inside its base. Primary clava and lateral cirrus arise on the same cirrophore, and a common membrane (extended margin of cirrophore) surrounds the base of primary clava and lateral cirrus. A very large and thick cuticular ring supports the cirrophore internally. The secondary clavae are large, comma-shaped flat sacs $(19 \mu \mathrm{m} \times 8 \mu \mathrm{m})$ flanking the mouth cone (Figs 8 , 9C). The leg I sense organ $(11 \mu \mathrm{m})$ is an unsegmented spine with a slightly swollen base and a terminal tube. The sense organs of leg II $(9 \mu \mathrm{m})$ and III $(9 \mu \mathrm{m})$ are unsegmented tapering spines. The fourth leg sense organ $(8 \mu \mathrm{m})$ is an elongate papilla with a basal van der Land's body and a terminal pore. The cirrus E $(46 \mu \mathrm{m})$ has a prominent cirrophorus, scapus and a long tapering flagellum.

Legs, Digits And Claws. The legs consist of coxa, femur, tibia and tarsus as found in all species of Florarctinae. A row of numerous cuticular stripes of unknown function marks the transition from femur to tibia (Fig. 8). The external digits are supported by internal hook-shaped peduncles. The external claw is simple and with a calcar. The internal claw has an accessory spine, but no calcar. All the claws are of the same size, however the external claws are thicker basally and the internal claws have an almost straight portion dorsally. An internal partition is evident as a small notch in each claw, dividing the claw in a basal portion and a distal portion.

BUCCO-PHARYNGEAL APPARATUS. The mouth cone is large with a terminal, very refractive cupola, through which the distal part of the stylet sheaths, protrude. The buccal tube (Fig. 9A-B) is $48 \mu \mathrm{m}$ long and thin and has a small refractive bulb anterior to the placoids. The stylets are $50 \mu \mathrm{m}$ long and very thin, each with a well-developed furca. The placoids are short, thick and slightly curved.

ReProductive System. Consists of a single ovary bearing several small oocytes. The ovary is $62 \mu \mathrm{m}$ long and is attached dorsally, at the level of the second pair of legs. The gonopore consists of a rosette with six large cells. The two cuticular seminal receptacles each consist of a spheroid vesicle and an S-shaped genital duct (Fig. 8). The cuticle is slightly elevated at each duct opening but does not form a true papilla. The anus is a trilobed cuticular system consisting of two large lateral lobes and a smaller posterior lobe.

\section{Ecology and distribution}

Known only from the type locality.

Higginsarctus lassei gen. et sp. nov. urn:1sid:zoobank.org:act:5086AB3C-F4CD-48ED-AE57-6D35C2EB14D7 Figs 10-11

Diagnosis (characters uniquely defining the taxon are written in bold)

Characterized by flat, oval secondary clavae. Unilobed antero-lateral alae with weakly undulating distal margins without indentations. Bilobed medio-lateral alae with medial pointed indentations. 
Medio-lateral alae smaller than antero-lateral alae. Bilobed postero-lateral alae with a medial arched identation. Postero-lateral alae larger than antero-lateral alae. Quadrilobed, rectangular caudal ala with 3 arched indentations, 1 medial and 2 lateral. Medial lobes of caudal ala smaller than lateral lobes. Leg sense organs I-III with similar length. Genital stoup present.

\section{Etymology}

The new species is dedicated to Lasse G. Hansen, the son of the first author.

\section{Material examined}

\section{Holotype}

CHILE • O; South Pacific Ocean; 335' S, 8751' W; depth 2475 m; 17 Jul. 1966; R.P. Higgins leg.; (RH 1270), R/V Anton Bruun, cruise 17; NHMD-293913.

\section{Description}

HABITUS. The holotypic female (Figs 10-11) is $143 \mu \mathrm{m}$ long from the anterior margin of the head to the posterior margin of the body. The body is ovoid, being broadest $(89 \mu \mathrm{m})$ at the level between the second and third pair of legs. The dorsal cuticle has four transverse inter-segmental folds: one anterior to the first pair of legs, two between the first and second pair of legs and one between the second and third pair of legs.

AlaE. Typical for the genus, eight alae, which are all clearly separated from each other, are present: frontal ala, a pair of antero-lateral alae, a pair of medio-lateral alae, a pair of postero-lateral alae and a single caudal ala (Figs 10, 11A). The antero-lateral alae are unilobed with weakly undulating distal margins without indentations. The medio-lateral alae which are smaller than the antero-lateral alae, each have a medial pointed indentation dividing each ala into two lobes of equal size. The postero-lateral alae which are larger than both the antero-lateral and medio-lateral alae, each have a medial arched indentation in the distal margin, dividing the ala into two lobes of equal size. The caudal ala has a deep medial, arched indentation and a pair of lateral, arched indentations dividing the ala into four lobes. The medial lobes are smaller than the lateral lobes. As in all species of the new genus, the proximal halve of the lateral and caudal alae is internally supported by continuous procuticle which sends out branching processes (ramuli) into the distal halve of the alae.

SENSORY ORGANS. The head is well defined from the body by a constriction and a complete set of sense organs is present. All the cephalic cirri consist of an hourglass-shaped scapus, a long tubular portion and a protruding flagellum. As in most other species of Florarctinae the scapus of each cirrus appears somewhat outsized, enveloping the internal sensory structures rather than lining them. The internal cirri $(41 \mu \mathrm{m})$ emerge from the frontal ala at the anterior margin of the head. The external cirri $(28 \mu \mathrm{m})$ are inserted ventrally and the median cirrus $(33 \mu \mathrm{m})$ mid-dorsally. Typical for the genus, the primary clava $(58 \mu \mathrm{m})$ is slightly curved and non-flexible (Fig. 11C). A van der Land's body is visible inside its base. Primary clava and lateral cirrus arise on the same cirrophore, and a common membrane (extended margin of cirrophore) surrounds the base of primary clava and lateral cirrus. A very large and thick cuticular ring supports the cirrophore internally. The secondary clavae are oval flat sacs $(11 \mu \mathrm{m} \times 7 \mu \mathrm{m})$ flanking the mouth cone. The leg I sense organ $(12 \mu \mathrm{m})$ is an unsegmented spine with a slightly swollen base and a terminal tube. The sense organs of leg II $(12 \mu \mathrm{m})$ and III $(11 \mu \mathrm{m})$ are unsegmented tapering spines. The fourth leg sense organ $(13 \mu \mathrm{m})$ is an elongate papilla with a basal van der Land's body and a terminal pore. The cirrus $\mathrm{E}(48 \mu \mathrm{m})$ has a prominent cirrophorus, scapus and a long tapering flagellum.

LegG, Digits AND CLAWS. The legs consist of coxa, femur, tibia and tarsus as found in all species of Florarctinae. The external digits are supported by internal hook-shaped peduncles. The external claw is simple and with a calcar. The internal claw has an accessory spine, but no calcar. All the claws are of the same size, however the external claws are thicker basally and the internal claws have an almost straight 


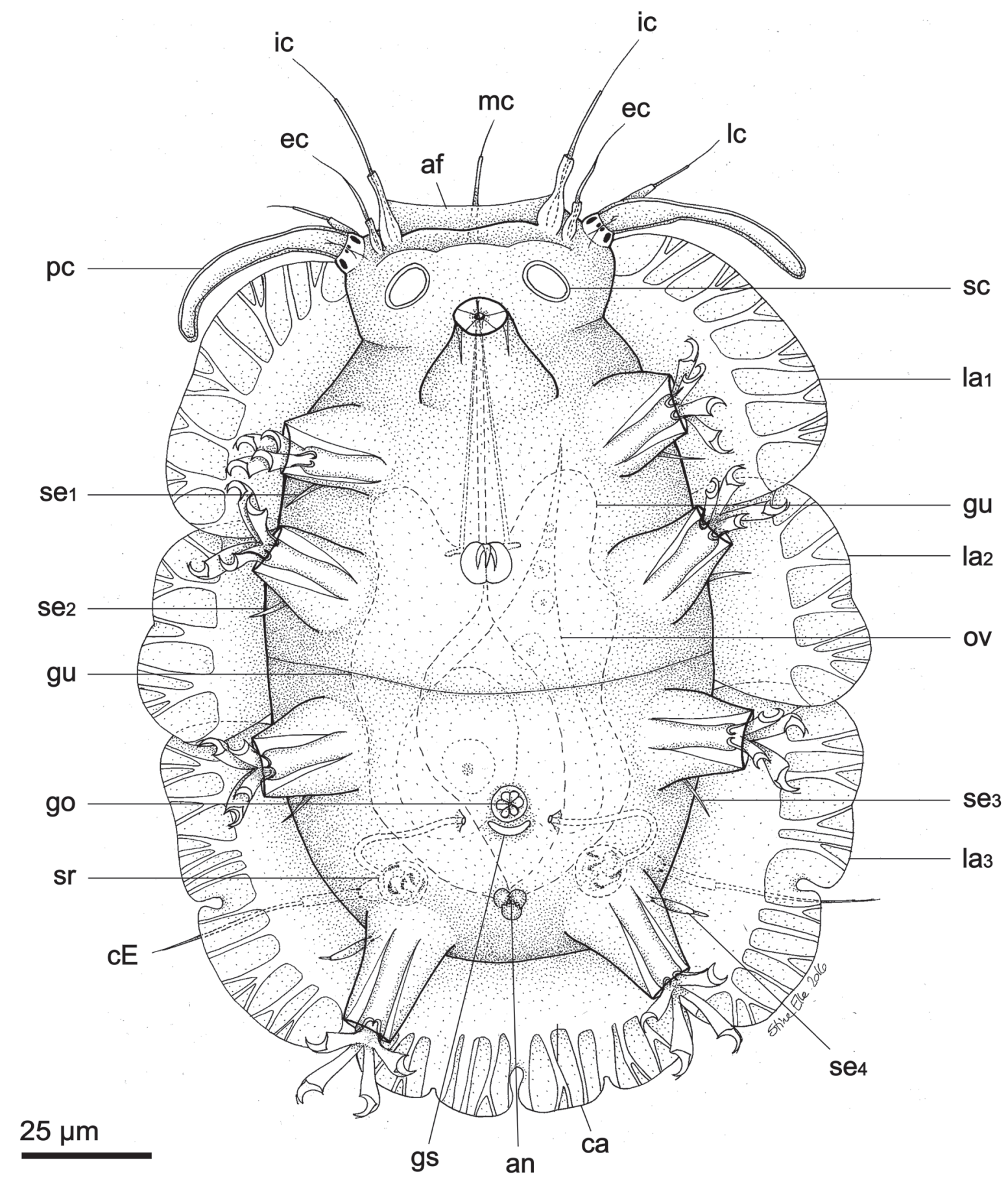

Fig. 10. Higginsarctus lassei gen. et sp. nov., holotype, ㅇ (NHMD-293913). Ventral overview. Abbreviations: see Material and methods. Drawing by Stine B. Elle. 

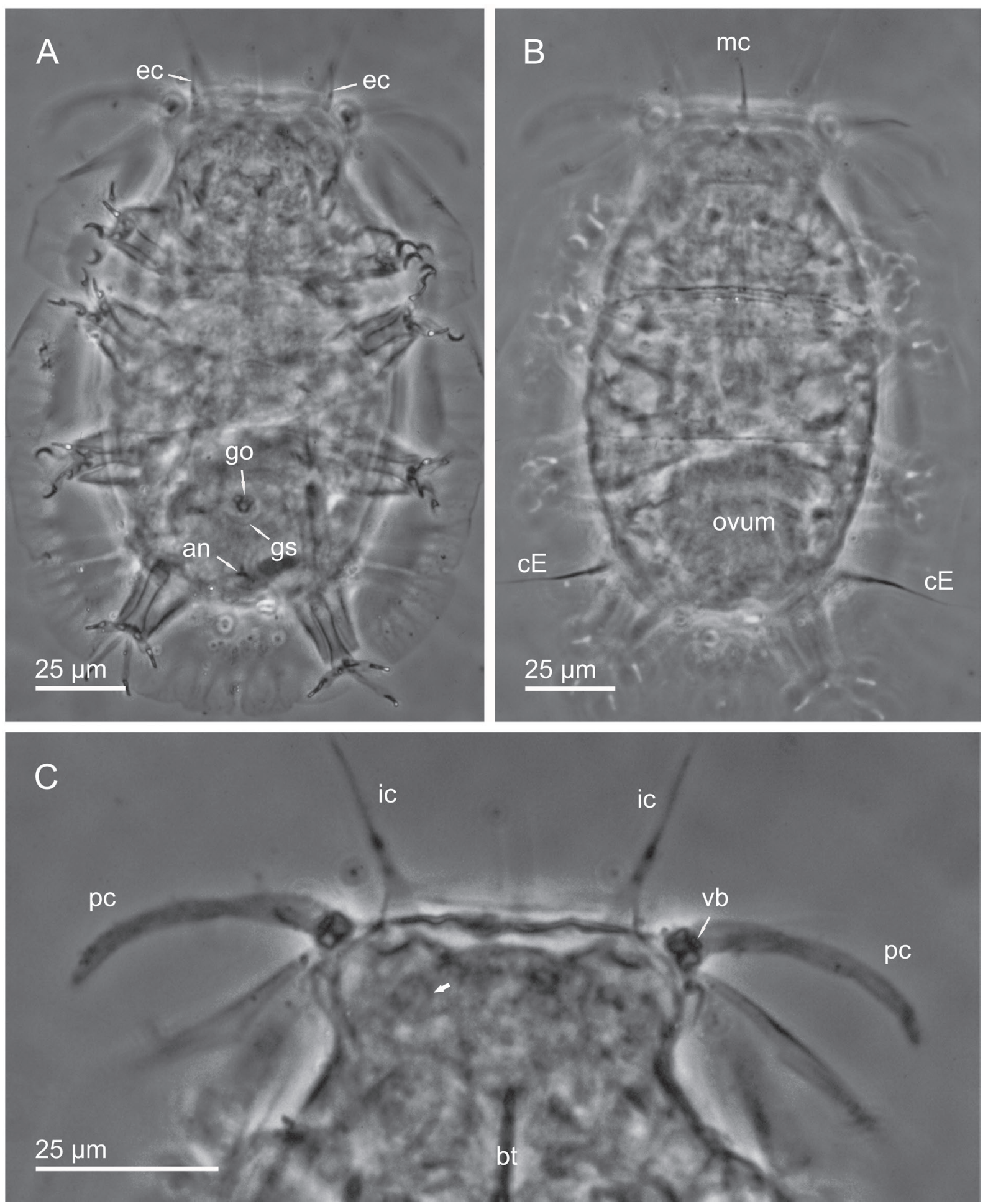

Fig. 11. PhC-micrographs of Higginsarctus lassei gen. et sp. nov., holotype, $q$ (NHMD-293913). A. Ventral overview. B. Dorsal overview showing the metameric folds of the dorsal cuticle. C. Close up on the head, ventral view showing the weak indication of secondary clava (white solid arrow), internal cirri and primary clavae with van der Land's body. Abbreviations: see Material and methods. 
portion dorsally. An internal partition is evident as a small notch in each claw, dividing the claw in a basal portion and a distal portion.

BuCCO-PHARYNGEAL APPARATUS. The mouth cone (Fig. 10) is large with a terminal, very refractive cupola. Only traces of the buccal tube $(44 \mu \mathrm{m})$, stylets $(47 \mu \mathrm{m})$, placoids and pharyngeal bulb are visible.

Reproductive system. Consists of a single ovary bearing numerous small oocytes and a single larger ovum. The ovary is $72 \mu \mathrm{m}$ long and is attached dorsally, at the level of the first pair of legs. The gonopore consists of a rosette with six large cells. Posterior to the rosette, the cuticle forms what appears in LM to be a broad fold which we interpret as the genital stoup. The two cuticular seminal receptacles each consist of a spheroid vesicle and an S-shaped genital duct. The cuticle is slightly elevated at each duct opening but does not form a true papilla. The anus is a trilobed cuticular system consisting of two large lateral lobes and a smaller posterior lobe.

\section{Ecology and distribution}

Known only from the type locality.

Higginsarctus martini gen. et sp. nov. urn:1sid:zoobank.org:act:0373D8D1-209D-4853-936F-CC4E5DA584CB

Figs $12-13$

Diagnosis (characters uniquely defining the taxon are written in bold)

Characterized by ovoid, dome-shaped secondary clavae. Bilobed antero-lateral alae with medial pointed indentations. Bilobed medio-lateral alae with medial pointed indentations. Medio-lateral alae smaller than antero-lateral alae. Trilobed postero-lateral alae each with anterior pointed indentation and posterior arched indentation. Postero-lateral alae larger than antero-lateral alae. Quadrilobed, round caudal ala with 3 arched indentations, 1 medial and 2 lateral. Medial lobes of caudal ala smaller than lateral lobes. Leg sense organs I-III with similar length. Genital stoup present.

\section{Etymology}

The new species is dedicated to Dr Martin Vinther Sørensen for his contributions to meiofauna research.

\section{Material examined}

Holotype

FRANCE • 9 ; North Atlantic Ocean, English Channel, Bay of Morlaix, Roscoff; $48^{\circ} 43^{\prime}$ N, $03^{\circ} 54^{\prime}$ W; depth 20-30 m; 15 Mar. 1982; R.M. Kristensen leg.; Dentalium sand; NHMD-293903.

\section{Description}

HaBitus. The holotypic female (Figs 12-13) is $159 \mu \mathrm{m}$ long from the anterior margin of the head to the posterior margin of the body. The body is ovoid, being broadest $(79 \mu \mathrm{m})$ at the level between the second and third pair of legs. Intersegmental folds are not recognisable.

AlaE.Typical for the genus, eight alae, which are all clearly separated from each other, are present: frontal ala, a pair of antero-lateral alae, a pair of medio-lateral alae, a pair of postero-lateral alae and a single caudal ala (Figs 12, 13A). The antero-lateral alae each have a medial pointed indentation dividing each ala into two lobes of equal size. The medio-lateral alae which are smaller than the antero-lateral alae, each have a medial pointed indentation dividing each ala into two lobes of equal size. The posterolateral alae which are larger than both the antero-lateral and medio-lateral alae, each have an anterior pointed indentation and a posterior arched indentation defining a small medial lobe and two larger lateral 


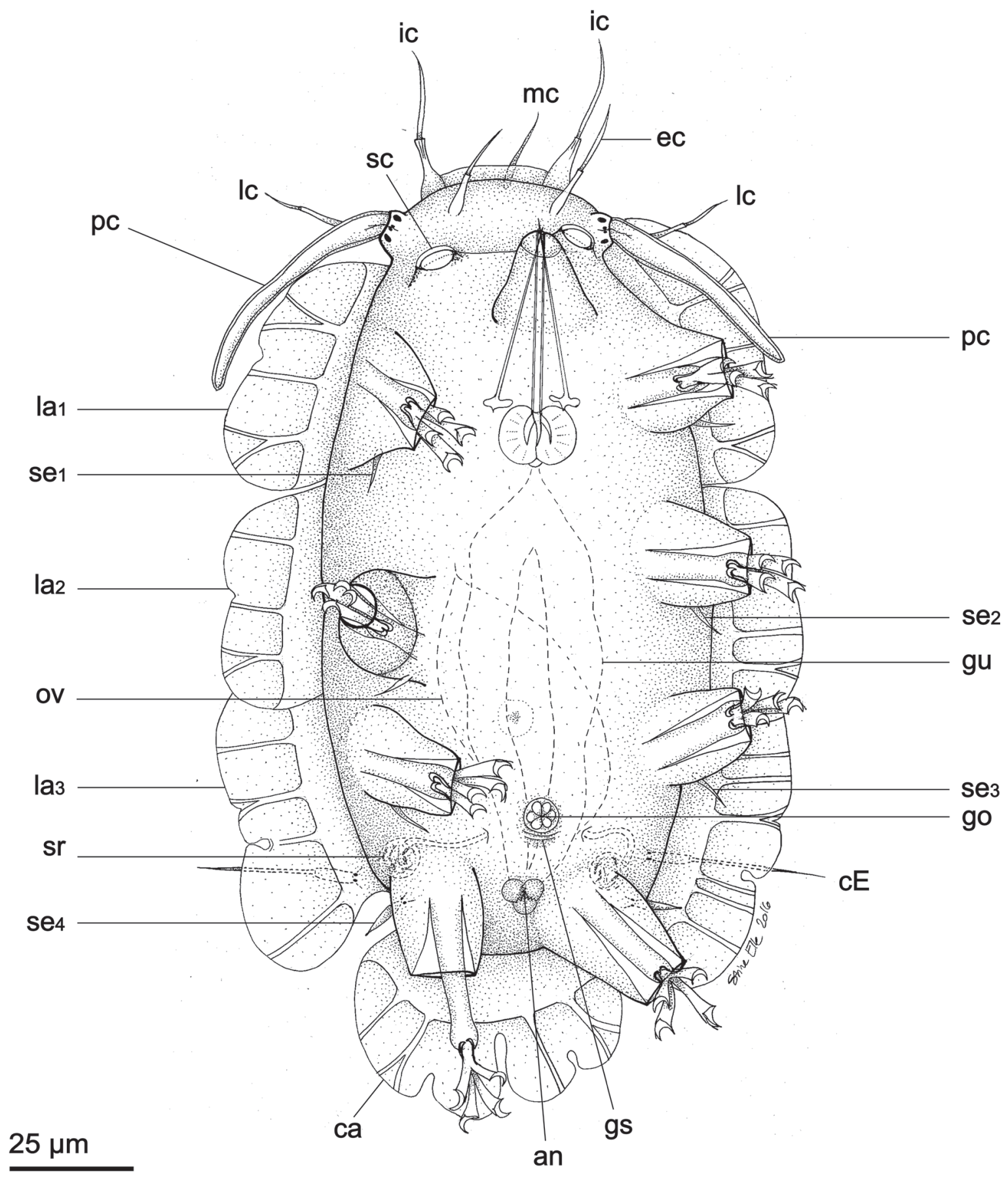

Fig. 12. Higginsarctus martini gen. et sp. nov., holotype, $q$ (NHMD-293903). Ventral overview. Abbreviations: see Material and methods. Drawing by Stine B. Elle. 
lobes. The caudal ala has an overall round shape with a deep medial, arched indentation and a pair of lateral, arched indentations dividing the ala into four lobes. The medial lobes are smaller than the lateral lobes. As in all species of the new genus, the proximal halve of the lateral and caudal alae is internally supported by continuous procuticle which sends out branching processes (ramuli) into the distal halve of the alae.
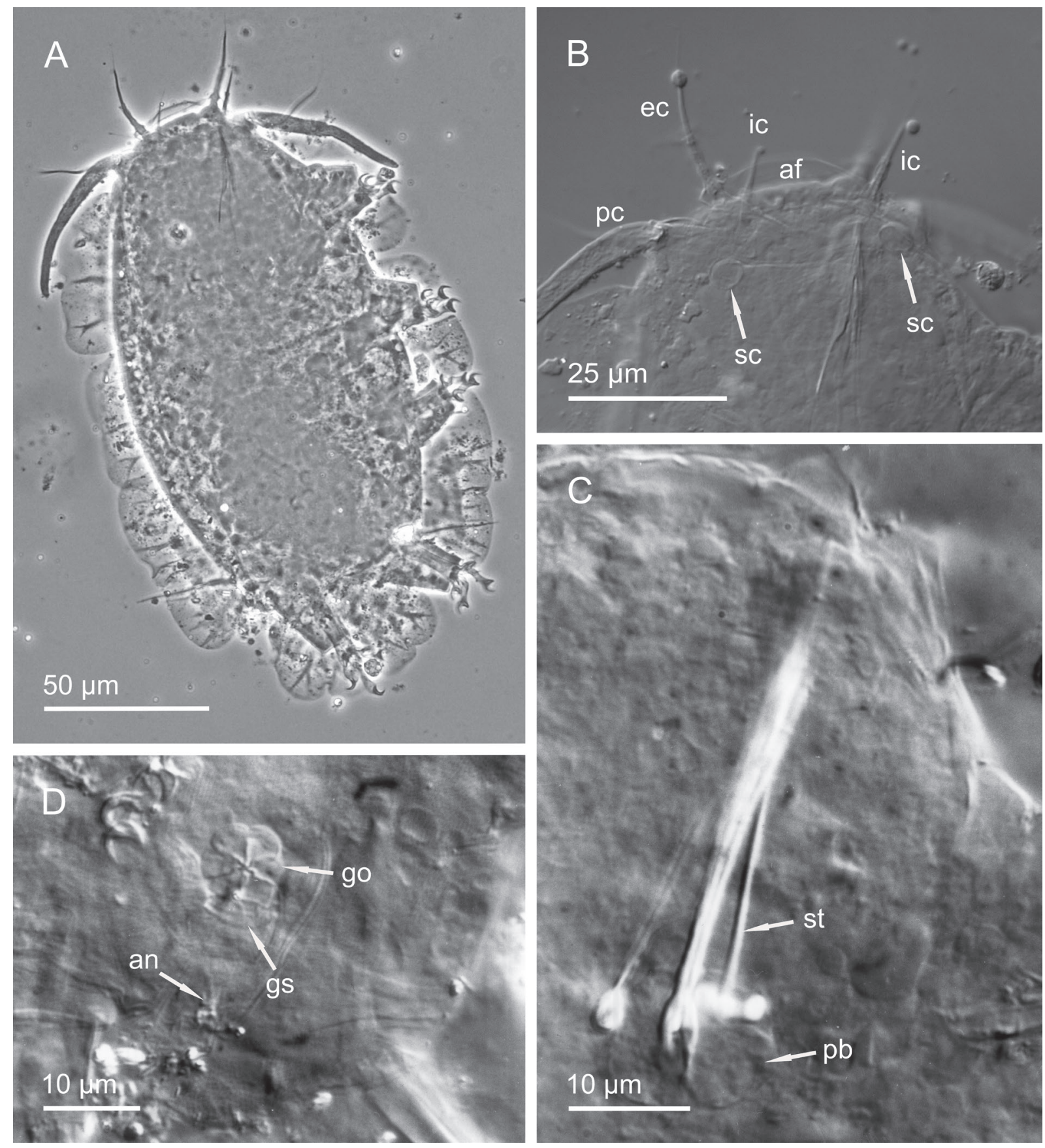

Fig. 13. Micrographs of Higginsarctus martini gen. et sp. nov., holotype, q (NHMD-293903). A. Overview (PhC). B. Close up on the head (DIC), ventral view showing the cephalic cirri and secondary clavae. C. Close up on the bucco-pharyngeal apparatus (DIC). D. Close up on the caudal region (DIC), ventral view showing the gonopore, genital stoup and anus. Abbreviations: see Material and methods. 
SENSORY ORGANS. The head is not well defined from the body and a complete set of sense organs is present. All the cephalic cirri consist of an hourglass-shaped scapus, a long tubular portion and a protruding flagellum. As in most other species of Florarctinae the scapus of each cirrus appears somewhat outsized, enveloping the internal sensory structures rather than lining them. The internal cirri $(33 \mu \mathrm{m})$ emerge from the frontal ala at the anterior margin of the head. The external cirri $(21 \mu \mathrm{m})$ are inserted ventrally and the median cirrus $(16 \mu \mathrm{m})$ mid-dorsally. Typical for the genus, the primary clava $(48 \mu \mathrm{m})$ is slightly curved and non-flexible (Figs 12, 13A). A van der Land's body is visible inside its base. Primary clava and lateral cirrus $(28 \mu \mathrm{m})$ arise on the same cirrophore, and a common membrane (extended margin of cirrophore) surrounds the base of primary clava and lateral cirrus. A very large and thick cuticular ring supports the cirrophore internally. The secondary clavae are ovoid, dome-shaped papillae $(6 \mu \mathrm{m} \times 3 \mu \mathrm{m})$ flanking the mouth cone. The leg I sense organ $(10 \mu \mathrm{m})$ is an unsegmented spine with a slightly swollen base and a terminal tube. The sense organs of leg II $(8 \mu \mathrm{m})$ and III $(8 \mu \mathrm{m})$ are unsegmented tapering spines. The fourth leg sense organ $(10 \mu \mathrm{m})$ is an elongate papilla with a basal van der Land's body and a terminal pore. The cirrus E $(42 \mu \mathrm{m})$ has a prominent cirrophorus, scapus and a long tapering flagellum.

Legs, Digits AND Claws. The legs consist of coxa, femur, tibia and tarsus as found in all species of Florarctinae. The external digits are supported by internal hook-shaped peduncles. The external claw is simple and with a calcar. The internal claw has an accessory spine, but no calcar. All the claws are of the same size, however the external claws are thicker basally and the internal claws have an almost straight portion dorsally. An internal partition is evident as a small notch in each claw, dividing the claw in a basal portion and a distal portion.

BuCCO-PHARYNGEAL APPARATUS. The mouth cone is large with a terminal, very refractive cupola, through which the distal part of the stylets protrudes (Figs 12, 13B). The buccal tube is $40 \mu \mathrm{m}$ long and thin (Fig. 13C). The stylets are $43 \mu \mathrm{m}$ long and very thin, each with a well-developed furca. The placoids are short and thick (Fig. 13C).

Reproductive SYSTEm. Consists of a single ovary in which only a single large ovum can be recognized. The ovary is $57 \mu \mathrm{m}$ long and is attached dorsally, at the level of the second pair of legs. The gonopore consists of a rosette with six large cells (Fig. 13D). Posterior to the rosette, the cuticle forms what appears in LM to be a broad fold which we interpret as the genital stoup. The two cuticular seminal receptacles each consist of a spheroid vesicle and an S-shaped genital duct. The cuticle is slightly elevated at each duct opening but does not form a true papilla. The anus is a trilobed cuticular system consisting of two large lateral lobes and a smaller posterior lobe.

\section{Ecology and distribution}

Known only from the type locality.

$$
\begin{aligned}
& \text { Higginsarctus laurae gen. et sp. nov. } \\
& \text { urn:1sid:zoobank.org:act:E4929598-4B3D-4932-A6FE-9B32DC74CF0D }
\end{aligned}
$$

Figs 14-16

Diagnosis (characters uniquely defining the taxon are written in bold)

Characterized by large, spherical secondary clavae. Trilobed antero-lateral alae each with pair of medial pointed indentations. Antero-lateral alae larger than postero-lateral alae. Bilobed mediolateral alae with medial pointed indentations. Medio-lateral alae smaller than postero-lateral alae. Bilobed postero-lateral alae with medial pointed identations. Bilobed, round caudal ala with deep 
medial pointed indentations. Leg sense organs I-III with similar length. Genital stoup present. Ventral cuticle with folia.

\section{Etymology}

The new species is dedicated to Laura Pavesi in acknowledgement of her continuous enthusiasm and effort to services the tardigrade collection at NHMD.

\section{Material examined}

Holotype

FRANCE • $\odot$; North Atlantic Ocean, English Channel, Bay of Morlaix, Roscoff; 48 $43^{\prime}$ N, $03^{\circ} 54^{\prime}$ W; depth 20-30 m; 15 Mar. 1982; R.M. Kristensen leg.; Dentalium sand; NHMD-293905.

Paratypes

FRANCE $\bullet 6$ 9 ; ; same collection data as for holotype; NHMD-293906 to NHMD-203011.

\section{Description}

HaBitus. The holotypic female (Figs 14-15) is $147 \mu \mathrm{m}$ long from the anterior margin of the head to the posterior margin of the body. The body is ovoid, being broadest $(83 \mu \mathrm{m})$ at the level between the second and third pair of legs. The dorsal cuticle has four transverse inter-segmental folds: one anterior to the first pair of legs, two between the first and second pair of legs and one between the second and third pair of legs. Five folia in the form of leaf-like structures (Fig. 14 and paratype Fig. 16C) are present on the ventral cuticle in the area between the legs, extending from the second pair of legs to the anus.

AlAE. Typical for the genus, eight alae, which are all clearly separated from each other, are present: frontal ala, a pair of antero-lateral alae, a pair of medio-lateral alae, a pair of postero-lateral alae and a single caudal ala (Figs 14, 15A, D and paratype Fig. 16A). The antero-lateral alae which are larger than the medio-lateral alae, each have a medial pair of pointed indentations, dividing the ala into a small medial lobe and two larger lateral lobes. The medio-lateral alae which are larger than the postero-lateral alae, each have a medial pointed indentation dividing the ala into two lobes of equal size. The posterolateral alae each have a medial pointed indentation dividing the ala into two lobes of equal size. The caudal ala has an overall round shape with a deep medial, pointed indentation dividing the ala into two lobes (Fig. 15D-E). As in all species of the new genus, the proximal halve of the lateral and caudal alae is internally supported by continuous procuticle which sends out branching processes (ramuli) into the distal halve of the alae (Figs 14, 15A, D).

SENSORY ORGANS. The head is well defined from the body by a constriction and a complete set of sense organs is present (Fig. 14). All the cephalic cirri consist of an hourglass-shaped scapus, a long tubular portion and a protruding flagellum. As in most other species of Florarctinae the scapus of each cirrus appears somewhat outsized, enveloping the internal sensory structures rather than lining them. The internal cirri $(35 \mu \mathrm{m})$ emerge from the frontal ala at the anterior margin of the head. The external cirri $(26 \mu \mathrm{m})$ are inserted ventrally and the median cirrus $(18 \mu \mathrm{m})$ mid-dorsally. Typical for the genus, the primary clava $(47 \mu \mathrm{m})$ is slightly curved and non-flexible (Figs 14, 15A). A van der Land's body is visible inside its base. Primary clava and lateral cirrus $(27 \mu \mathrm{m})$ arise on the same cirrophore, and a common membrane (extended margin of cirrophore) surrounds the base of primary clava and lateral cirrus. A very large and thick cuticular ring supports the cirrophore internally. The secondary clavae are large, spherical papillae $(8 \mu \mathrm{m} \times 5 \mu \mathrm{m})$ flanking the mouth cone (Fig. 15B-C and paratype Fig. 16B). A small refractive organ is visible inside the base of each clavae. The leg I sense organ $(15 \mu \mathrm{m})$ is a slightly segmented spine with a long swollen base and a terminal tube. The sense organs of leg II (14 $\mu \mathrm{m})$ and III $(14 \mu \mathrm{m})$ are unsegmented tapering spines. The fourth leg sense organ $(18 \mu \mathrm{m})$ is an elongate papilla with 


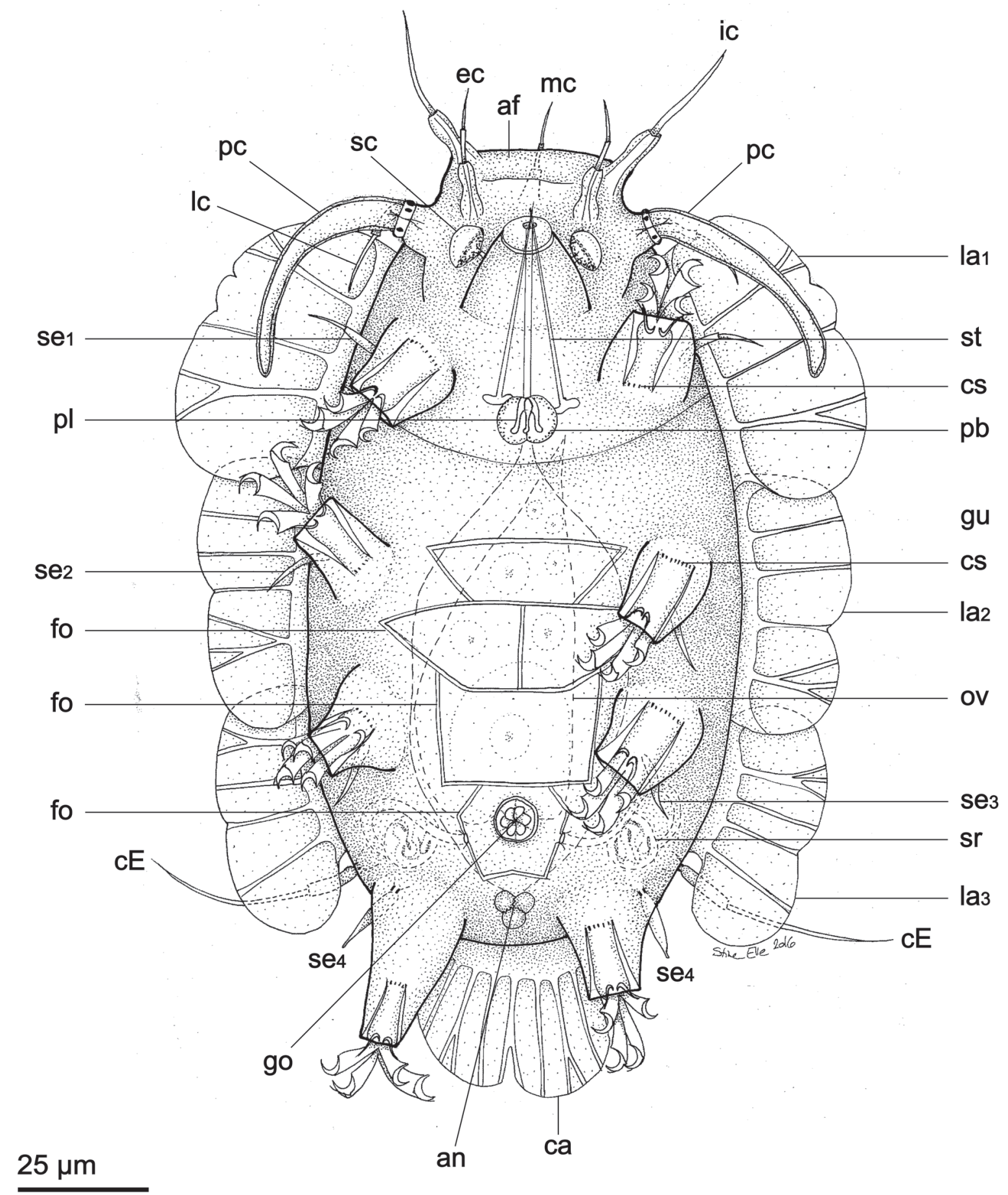

Fig. 14. Higginsarctus laurae gen. et sp. nov., holotype, $q$ (NHMD-293905). Ventral overview. Abbreviations: see Material and methods. Drawing by Stine B. Elle. 
a basal van der Land's body and a terminal pore (Fig. 15D-E). The cirrus E (45 $\mu \mathrm{m})$ has a prominent cirrophorus, scapus and a long tapering flagellum (Fig. 15D-E)

Legs, Digits And Claws. The legs consist of coxa, femur, tibia and tarsus as found in all species of Florarctinae. A row of numerous cuticular stripes of unknown function marks the transition from femur to tibia (Figs 14, 15A). The external digits are supported by internal hook-shaped peduncles. The external
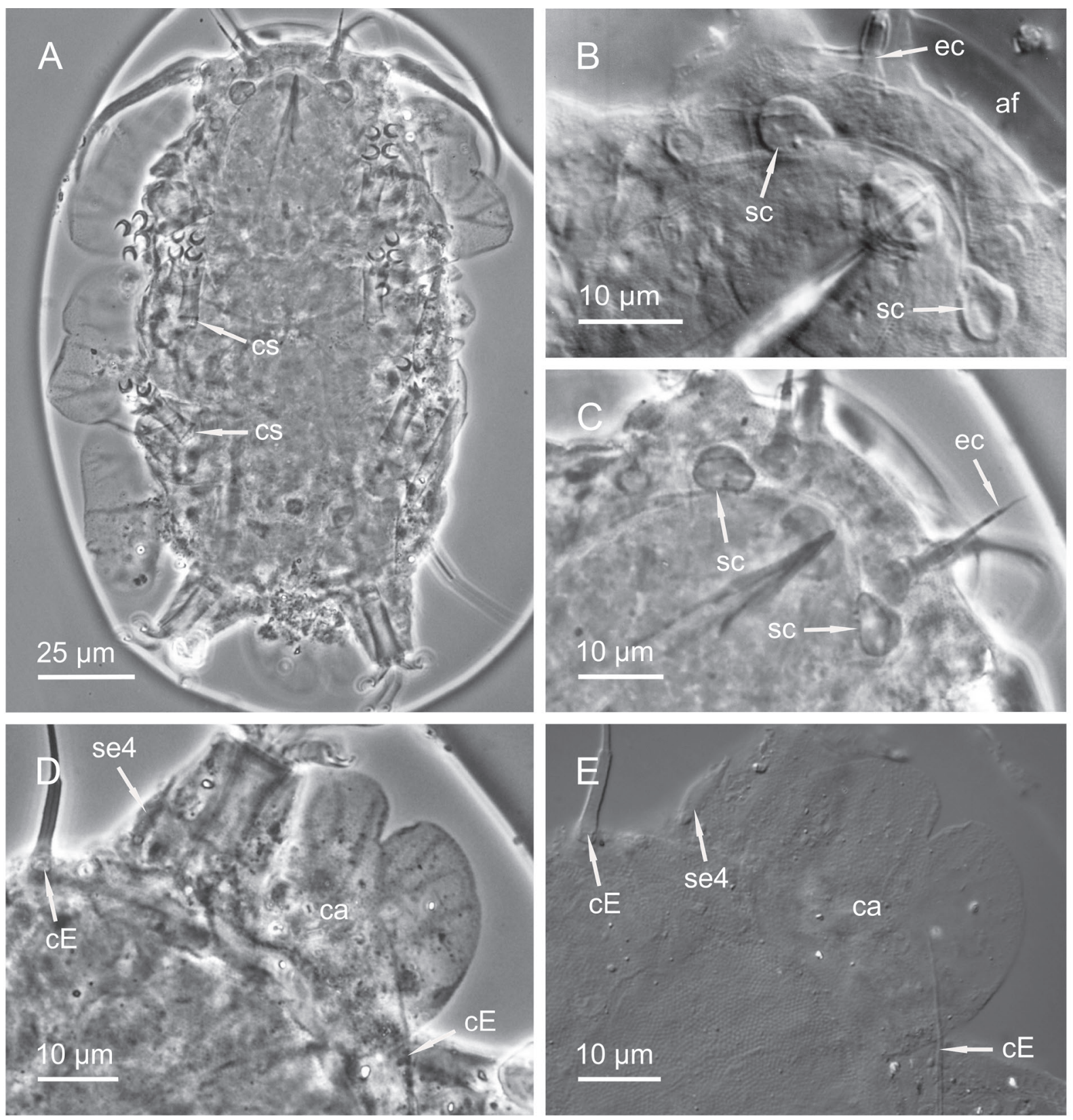

Fig. 15. Micrographs of Higginsarctus laurae gen. et sp. nov., holotype, $q$ (NHMD-293905). A. Overview $(\mathrm{PhC})$. B. Close up on the head (DIC), ventral view showing the secondary clavae. C. Close up on the head $(\mathrm{PhC})$, ventral view showing the secondary clavae. D. Close up on the caudal ala $(\mathrm{PhC})$, dorsal view showing the procuticular ramuli. E. Close up on the caudal ala (DIC), dorsal view showing the epicuticular pillars. Abbreviations: see Material and methods. 
claw is simple and with a calcar. The internal claw has an accessory spine, but no calcar. All the claws are of the same size, however the external claws are thicker basally and the internal claws have an almost straight portion dorsally. An internal partition is evident as a small notch in each claw, dividing the claw in a basal portion and a distal portion.

BucCo-Pharyngeal APPARATus. The mouth cone (Figs 14, 15B-C and paratype Fig. 16B) is large with a terminal, very refractive cupola, through which the distal part of the stylets protrudes. The buccal tube is $35 \mu \mathrm{m}$ long and thin and has a small refractive bulb anterior to the placoids. The stylets are $36 \mu \mathrm{m}$ long and very thin, each with a well-developed furca. The placoids are short, thick and slightly curved (paratype Fig. 16D). Each placoid has a droplet-shaped terminal swelling.
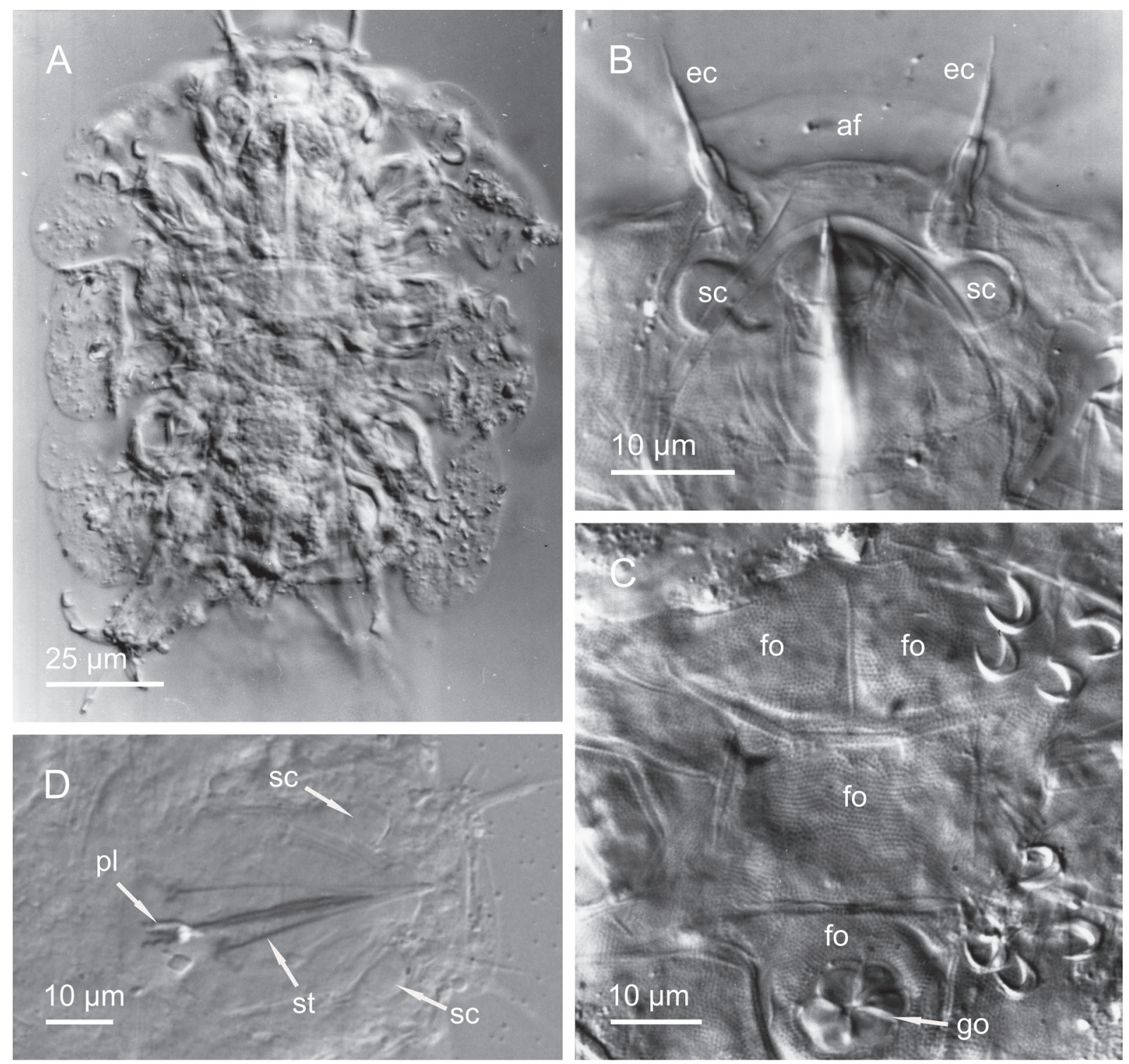

Fig. 16. DIC-micrographs of Higginsarctus laurae gen. et sp. nov. A. Paratype, ㅇ (NHMD-293907). Overview. B-D. Paratype, $q$ (NHMD-293908). B. Close up on the head, ventral view showing the external cirri and secondary clavae. C. Close up on the caudal region, ventral view showing the folia and gonopore. D. Close up on the bucco-pharyngeal apparatus. Abbreviations: see Material and methods. 
Reproductive system. Consists of a single ovary bearing numerous small oocytes and a single larger ovum. The ovary is $83 \mu \mathrm{m}$ long and is attached dorsally, at the level of the first pair of legs. The gonopore is inserted on a large folium and consists of a rosette with six large cells (Fig. 14 and paratype Fig. 16C). The two cuticular seminal receptacles each consist of a spheroid vesicle and an S-shaped genital duct (Fig. 14). The cuticle is slightly elevated at each duct opening but does not form a true papilla. The anus is a trilobed cuticular system consisting of two large lateral lobes and a smaller posterior lobe.

\section{Paratypes}

The 6 paratypes NHMD-293906 to NHMD-293911 are all mature females with a body length ranging from $118 \mu \mathrm{m}$ to $139 \mu \mathrm{m}$, body width from $60 \mu \mathrm{m}$ to $73 \mu \mathrm{m}$ and primary clava length from $39 \mu \mathrm{m}$ to $42 \mu \mathrm{m}$.

\section{Ecology and distribution}

Known only from the type locality.

Higginsarctus alatus (Gomes-Júnior, E. Santos, da Rocha, P.J.P. Santos \& Fontoura, 2018) gen. et comb. nov.

Figs $17-18$

Amended diagnosis (characters uniquely defining the taxon are written in bold)

Characterized by flat, bilobed secondary clavae. Unilobed, rectangular antero-lateral alae with weakly undulating distal margins without indentations. Unilobed, rectangular medio-lateral alae with weakly undulating distal margins without indentations. Antero-lateral alae and medio-lateral alae similar in size. Bilobed postero-lateral alae with a medial arched identation. Postero-lateral alae larger than antero-lateral alae and medio-lateral alae. Bilobed, rectangular caudal ala with deep arched identation medially. Lobes of the caudal ala nearly rectangular. Leg sense organs I-III highly different in length. Genital stoup present. Duct openings of seminal receptacles with true papillae.

\section{Material examined}

Holotype

BRAZIL • Southwestern Atlantic Ocean, Potiguar Basin, Rio Grande do Norte State; $04^{\circ} 37^{\prime} \mathrm{S}, 36^{\circ} 45^{\prime} \mathrm{W}$; depth $150 \mathrm{~m}$; 2009; bioclastic and lithoclastic sand; P. Fontoura (C.VII-84).

\section{Paratype}

BRAZIL • 1 spec.; same collection data as for holotype; P. Fontoura (C.VII-87).

\section{Remarks}

The results of our examination of the species described as Ligiarctus alatus confirm the presence of large, rigid and backwards bending primary clavae supported by strong internal cuticular structures at their bases, proximal part of the alae internally supported by procuticle which sends out branching processes (ramuli) into the distal part of the alae, and all claws with a small internal notch. Furthermore, it is evident that this species has three pairs of lateral alae. Thus, conforming to the diagnosis of Higginsarctus gen. nov., the species is here transferred to the new genus as Higginsarctus alatus gen. et comb. nov. In addition, our observations revealed the presence of a genital stoup (Figs 17B, 18A) and genital papillae (Figs 17B, 18A). We were also able to determine the shape of the secondary clavae (Figs 17A, 18B). As a consequence of the new information attained, the diagnosis of Higginsarctus alatus gen. et comb. nov. is amended accordingly.

\section{Ecology and distribution}

Known only from the type locality. 
A

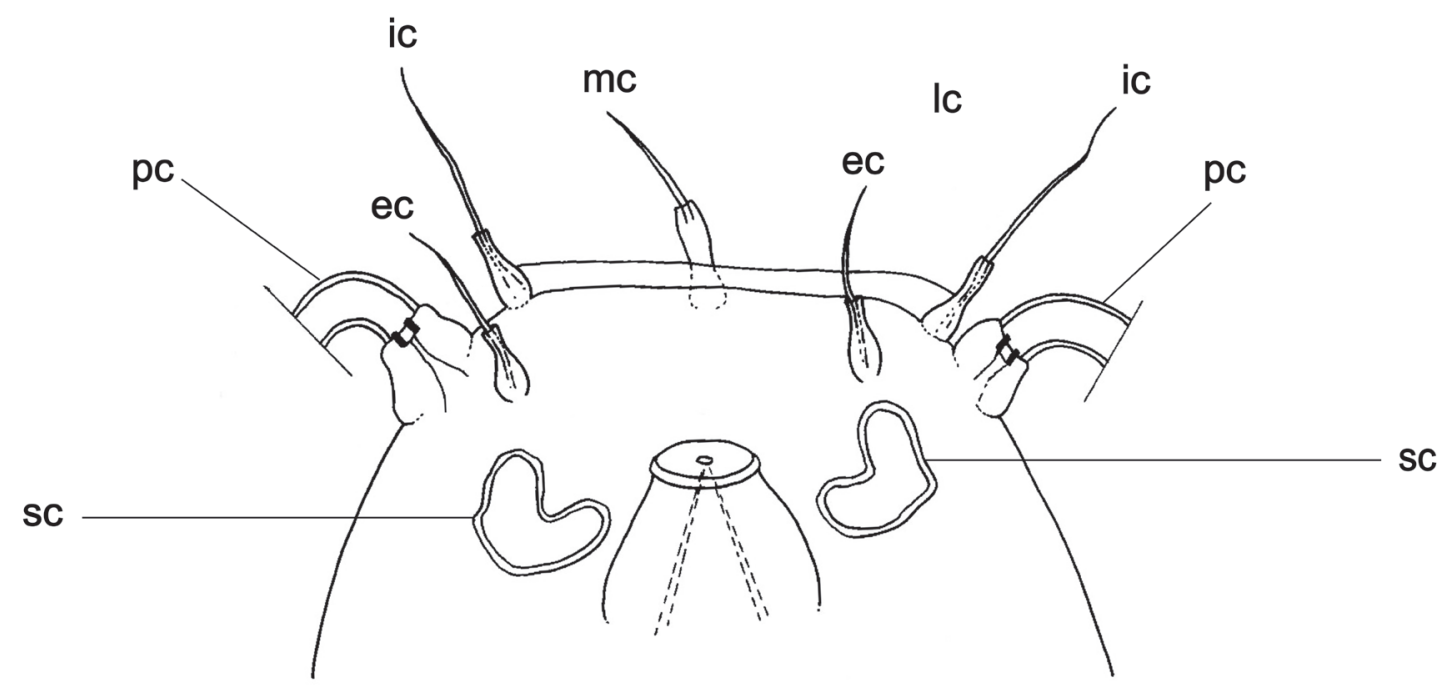

$20 \mu \mathrm{m}$

B

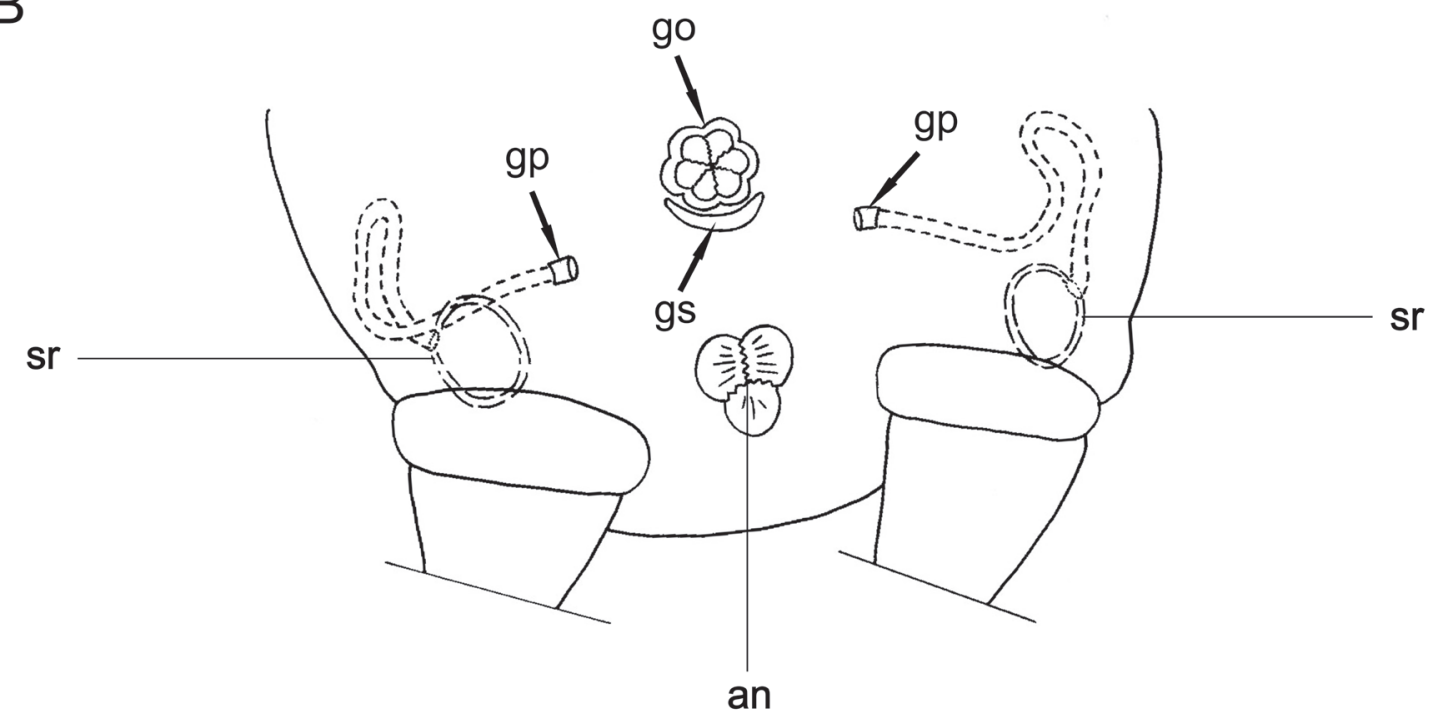

$20 \mu \mathrm{m}$

Fig. 17. Higginsarctus alatus (Gomes-Júnior, E. Santos, da Rocha, P.J.P. Santos \& Fontoura, 2018) gen. et comb. nov. A. Paratype (C.VII-87). Close up on the head, ventral view showing the cephalic cirri and secondary clavae. B. Holotype (C.VII-84). Close up on the caudal region, ventral view showing the gonopore, genital stoup, anus and seminal receptacles with genital papillae. Abbreviations: see Material and methods. Drawing by Stine B. Elle. 

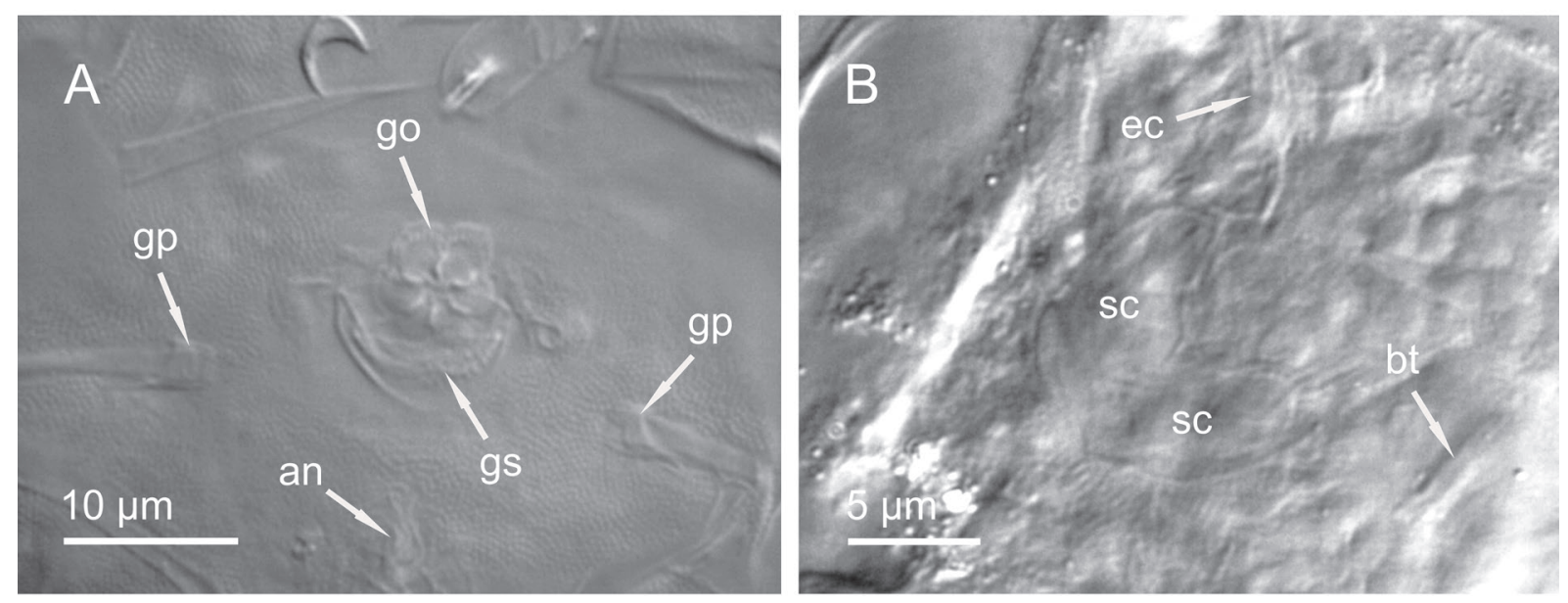

Fig. 18. Higginsarctus alatus (Gomes-Júnior, E. Santos, da Rocha, P.J.P. Santos \& Fontoura, 2018) gen. et comb. nov. A. Holotype (C.VII-84). Close up on the caudal region, ventral view showing the gonopore, genital stoup, anus and genital papillae. B. Paratype (C.VII-87). Close up on the secondary clava. Abbreviations: see Material and methods.

Higginsarctus gen. nov., sp. ind.

\section{Material examined}

FRANCE 1 two-clawed larva; North Atlantic Ocean: English Channel, Bay of Morlaix, $48^{\circ} 43^{\prime} \mathrm{N}$, 0354' W, depth 20-30 m; 15 Mar. 1982; R.M. Kristensen leg.; Dentalium sand; NHMD293912.

USA -2 + 9 , adults; Atlantic Ocean: South Carolina; $33^{\circ} 03.7^{\prime} \mathrm{N}, 77^{\circ} 22.07^{\prime} \mathrm{W}$; depth $289 \mathrm{~m}$; 19 Nov. 1983; R.P. Higgins (RH 1839); R/V Cape Hatteras; medium phosphorite sand; NHMD-293915, NHMD293917 - 1 two-clawed larva; same collection data as for preceding; NHMD-293916.

\section{Remarks}

Among the collected material from South Carolina, USA, two adult females were found, both having large, rigid and backwards bending primary clavae supported by strong internal cuticular structures at their bases, as well as three pairs of lateral alae supported by ramuli. These specimens likely present yet another species of Higginsarctus gen. nov., different to the new species described above. Unfortunately, further details cannot be accessed due to the poor condition of the specimens.

In addition to the two unidentifiable adult specimens of Higginsarctus gen. nov., two larval specimens were found; a 2-clawed larva from Roscoff, France and a 2-clawed larva from South Carolina, USA. Both larvae possess large, rigid and backwards bending primary clavae supported by strong internal cuticular structures at their bases, a character shared by Ligiarctus and Higginsarctus gen. nov. At this larval stage, alae are not present. Co-occurring only with adult specimens of Higginsarctus gen. nov. (no adult specimens of Ligiarctus were found in the samples), these larvae most likely belongs to the new genus. However, the conclusion as to whether they belong to Ligiarctus or Higginsarctus gen. nov. cannot be made with certainty.

Genus Ligiarctus Renaud-Mornant, 1982 (emended by Gomes-Júnior et al. 2018)

\section{Type species}

Ligiarctus eastwardi Renaud-Mornant, 1982. 


\section{Amended diagnosis}

A genus of Florarctinae with narrow head. Wide implementation of the primary clavae occupying the lateral edge of the head. Large, rigid and backwards bending primary clavae (shared with Higginsarctus gen. nov.) supported by strong internal cuticular structures at their bases. Frontal and caudal ala (without procuticular support) present in females. Frontal ala absent in males. Claws of external digits with internal distal notch.

\section{Material examined}

\section{Holotype of Ligiarctus eastwardi Renaud-Mornant, 1982}

USA • ${ }^{\top}$, adult; Atlantic Ocean: North Carolina; $34^{\circ} 07.3^{\prime}$ N, 7557. $7^{\prime}$ W; depth 400 m; 1974; B.C. Coull and R.P. Higgins; R/V Eastward; fine sand; MNHN AH551.

\section{Other material}

USA • 1 क; Atlantic Ocean, North Carolina; $34^{\circ} 07.4^{\prime}$ N, $75^{\circ} 57.0^{\prime}$ W; depth 439 m; 16 Nov. 1983; R.P. Higgins leg. (RH 1834); R/V Cape Hatteras; NHMD-293914.

\section{Remarks}

Following the exclusion of Ligiarctus alatus (= Higginsarctus alatus gen. et comb. nov.) from Ligiarctus, the genus diagnosis is amended to include only characters exhibited by Ligiarctus eastwardi.

The original description of Ligiarctus eastwardi by Renaud-Mornant (1982) included only males. In the present study, we were able to obtain information on female characters of Ligiarctus eastwardi for the first time, from the single female collected at the type locality in 1983. The specimen is clearly an adult female with evident seminal receptacles and typical female gonopore consisting of a rosette of six cells. The female is $161 \mu \mathrm{m}$ long from the anterior margin of the head to the posterior margin of the body. The body is ovoid, being broadest $(81 \mu \mathrm{m})$ at the level between the second and third pair of legs. The primary clava is $53 \mu \mathrm{m}$ long and slightly curved. Secondary clavae are not recognizable. A small frontal ala is evident, extending between the internal cirri. The caudal ala is disc-shaped without any procuticular support.

Comparing the female specimen to the holotypic male, strong secondary sexual dimorphism is indicated by body size, clava length and by the presence of a frontal ala in females. The male is much smaller $(109 \mu \mathrm{m})$ than the female $(161 \mu \mathrm{m})$, and the primary clavae proportionally much longer $(52 \mu \mathrm{m})$.

\section{Discussion}

The new genus shows affinity to each of the other genera in Florarctinae as follows: it shares with Florarctus and Wingstrandarctus the presence of lateral alae (absent in Ligiarctus); the presence of procuticular support in the alae is shared with Florarctus (absent in Wingstrandarctus and Ligiarctus) and the large, rigid and backwards bending primary clava is shared with Ligiarctus only. On the other hand, Higginsarctus gen. nov. is easily distinguished from all the other genera in Florarctinae by the presence of six lateral alae which can be two or four in Florarctus, four in Wingstrandarctus, or absent in Ligiarctus and by the special ramuli which is different to caestus in Florarctus and absent in both Wingstrandarctus and Ligiarctus. An interesting difference between Higginsarctus gen. nov. and Florarctus is that while the shape and position of caesti (especially in the caudal ala) varies considerably between species of Florarctus and is often used as a character in the delineation of species (e.g., Fujimoto 2015; AnguasEscalante et al. 2020), the overall configuration of the ramuli is quite conservative in Higginsarctus gen. nov. with little taxonomic signal between species. On the other hand, the shape of each individual ramulus highly varies within the alae of the same specimen/species. Higginsarctus gen. nov. also differs from Florarctus and Wingstrandarctus in the shape of the secondary clava. In the latter two genera, the 
secondary clavae shows little variation between species and can be either trilobed (y-shaped) inserted separately, or fused to form a sensory plate around the mouth, whereas in Higginsarctus gen. nov. they can be unilobed or bilobed, never trilobed nor fused, and their shape uniquely defines each species.

The discovery of the new taxa described above as well as several new features not previously known (e.g., three lateral alae, genital stoup, ventral folia), highlights the fact that although Florarctinae may be considered one of the more well-studied subfamilies of marine tardigrades, there is much additional diversity that awaits detection.

From a biogeographical perspective, the new genus greatly extends the known geographic and bathymetric distribution of species of Florarctinae. Compared to the genera Florarctus and Wingstrandarctus who shows affinity to warm and shallow sites (Fujimoto 2015; Kaczmarek et al. 2015; Anguas-Escalante et al. 2020; Gąsiorek et al. 2021), members of Higginsarctus gen. nov. inhabit deeper and colder sites. Higginsarctus signeae gen. et sp. nov. extends the northernmost range from $48^{\circ} 46^{\prime} \mathrm{N}$ (Florarctus acer Renaud-Mornant, 1989) to $61^{\circ} 23^{\prime} \mathrm{N}$, whereas Higginsarctus lassei gen. et sp. nov. extends the deepest range from $400 \mathrm{~m}$ (Ligiarctus) to $2475 \mathrm{~m}$.

\section{Acknowledgements}

The authors are grateful to P. Fontoura (Department of Biology, Faculty of Sciences, University of Porto, Portugal) for the loan of the type material of Higginsarctus alatus gen. et comb. nov., to MNHN for the loan of the type material of Ligiarctus eastwardi and to NHMD for the provision of work space and lab facilities and the reviewers who provided valuable comments to the manuscript. We also thank Stine Elle who skillfully prepared line drawing illustrations from our camera lucida drawings. J.G. Hansen was supported by the Carlsberg Foundation (grant numbers CF 2012_01_0127 and CF 150189). R.M. Kristensen was supported by the Carlsberg Foundation (grant numbers CF 2009_01_0053; CF 2012_01_0123 and CF 16-0236) and by the Danish Natural Science Research Council (grant number FNU 272-08-0576).

\section{References}

Anguas-Escalante A., de Jesús-Navarrete A., DeMilio E., Pérez-Pech W.A. \& Hansen J.G. 2020. A new species of Tardigrada from a Caribbean reef lagoon, Florarctus yucatanensis sp. nov. (Halechiniscidae: Florarctinae). Cahiers de Biologie marine 61: 377-385. https://doi.org/10.21411/CBM.A.CD1B185A

Fontoura P., Bartels P.J., Jørgensen A., Kristensen R.M. \& Hansen J.G. 2017. An illustrated dichotomous key to the genera of marine heterotardigrades (Tardigrada). Zootaxa 4294: 1-45.

https://doi.org/10.11646/zootaxa.4294.1.1

Fujimoto S. 2015. Halechiniscidae (Heterotardigrada, Arthrotardigrada) of Oura Bay, Okinawajima, Ryuku Islands, with descriptions of three new species. ZooKeys 483: 149-166.

https://doi.org/10.3897/zookeys.483.8936

Fujimoto S., Jørgensen A. \& Hansen J.G. 2017. A molecular approach to arthrotardigrade phylogeny (Heterotardigrada, Tardigrada). Zoologica Scripta 46: 496-505. https://doi.org/10.1111/zsc.12221

Gąsiorek P., Kristensen D.M. \& Kristensen R.M. 2021. Extreme secondary sexual dimorphism in the genus Florarctus (Heterotardigrada: Halechiniscidae). Marine Biodiversity 51: 52. https://doi.org/10.1007/s12526-021-01183-y

Gomes-Júnior E., Santos É., da Rocha C.M.C., Santos P.J.P. \& Fontoura P. 2018. A new species of Ligiarctus (Tardigrada, Arthrotardigrada) from the Brazilian continental shelf, Southwestern Atlantic Ocean. Marine Biodiversity 48: 5-12. https://doi.org/10.1007/s12526-017-0709-0 
Hansen J.G. 2004. Marine Arthrotardigrades with emphasis on the Faroe Bank species. MSc Thesis, Zoological Museum, University of Copenhagen, Denmark.

Hansen J.G. 2005. The ongoing investigation of the Faroe Bank tardigrade fauna. Frøđskapparit supplementum. Proceedings from the BIOFAR Symposium, Tórshavn, Faroe Islands, 24-26 April 2003, North-East Atlantic marine benthic organisms in the Faroes - Taxonomy, Distribution and Ecology: 220-223.

Hansen J.G. \& Kristensen R.M. 2020. Tardigrada. In: Schmidt-Rhaesa A. (ed.) Guide to the Identification of Marine Meiofauna: chapter 23: 428-444. Pfeil-Verlag, Munich, Germany.

Hansen J.G., Jørgensen A. \& Kristensen R.M. 2001. Preliminary studies of the tardigrade fauna of the Faroe Bank. Zoologischer Anzeiger 240: 385-393. https://doi.org/10.1078/0044-5231-00046

Hansen J.G., D'Addabbo Gallo M. \& De Zio Grimaldi S. 2003. A comparison of morphological characters within the genus Rhomboarctus (Tardigrada: Heterotardigrada) with the description of two new species. Zoologischer Anzeiger 242: 83-96. https://doi.org/10.1078/0044-5231-00089

Hansen J.G., Kristensen R.M., Jørgensen A., Accogli G., D’Addabbo R. \& Gallo M. 2016. Postembryonic development, paedomorphosis, secondary sexual dimorphism and population structure of a new Florarctus species (Tardigrada, Heterotardigrada). Zoological Journal of the Linnean Society 178: 871877. https://doi.org/10.1111/zoj.12436

Kaczmarek Ł., Bartels P.J., Roszkowska M. \& Nelson D.R. 2015. The zoogeography of marine Tardigrada. Zootaxa 4037: 1-189. https://doi.org/10.11646/zootaxa.4037.1.1

Kristensen R.M. 1983. Loricifera, a new phylum with Aschelminthes characters from the meiobenthos. Zeitschrift für Zoologische Systematik und Evolutionsforschung 21: 163-180.

https://doi.org/10.1111/j.1439-0469.1983.tb00285.x

Kristensen R.M. 1984. On the biology of Wingstrandarctus corallinus nov. gen. et spec., with notes on the symbiontic bacteria in the subfamily Florarctinae (Arthrotardigrada). Videnskabelige Meddelelser fra Dansk Naturhistorisk Forening 145: 201-218.

Kristensen R.M. \& Renaud-Mornant J. 1983. Existence d'Arthrotardigrades semi-benthiques de genres nouveaux de la sous-famille des Styraconyxinae subfam. nov. Cahiers de Biologie marine 24: 337-353.

Nørrevang A., Brattegard T., Josefson A.B., Sneli J.-A. \& Tendal O.S. 1994. List of BIOFAR stations. Sarsia 79: 165-180. https://doi.org/10.1080/00364827.1994.10413557

Renaud-Mornant J. 1982. Sous-famille et genre nouveaux de Tardigrades marins (Arthrotardigrada). Bulletin du Muséum national d'histoire naturelle Série 4e 4 (1-2): 89-94.

Renaud-Mornant J. 1987. Halechiniscidae nouveaux de sables coralliens tropicaux (Tardigrada, Arthrotardigrada). Bulletin du Muséum national d'histoire naturelle 9 (2): 353-373.

Renaud-Mornant J. 1989. Espèces nouvelles de Florarctinae de l'Atlantique Nord-Est et du Pacifique Sud (Tardigrada, Arthrotardigrada). Bulletin du Muséum national d'histoire naturelle, Section A, Zoologie Biologie et Écologie animales 11 (3): 571-592.

van der Land J. 1968. Florarctus antillensis, a new tardigrade from the coral sands of Curaçao. Studies on Fauna of Curaçao and other Caribbean Islands 25: 140-146.

Manuscript received: 6 April 2021

Manuscript accepted: 21 June 2021

Published on: 17 August 2021

Topic editor: Rudy Jocqué 
Section editor: Daniel Stec

Desk editor: Pepe Fernández

Printed versions of all papers are also deposited in the libraries of the institutes that are members of the EJT consortium: Muséum national d'histoire naturelle, Paris, France; Meise Botanic Garden, Belgium; Royal Museum for Central Africa, Tervuren, Belgium; Royal Belgian Institute of Natural Sciences, Brussels, Belgium; Natural History Museum of Denmark, Copenhagen, Denmark; Naturalis Biodiversity Center, Leiden, the Netherlands; Museo Nacional de Ciencias Naturales-CSIC, Madrid, Spain; Real Jardín Botánico de Madrid CSIC, Spain; Zoological Research Museum Alexander Koenig, Bonn, Germany; National Museum, Prague, Czech Republic. 